\title{
Characterization of Damage and Regeneration in Cultured Avian Utricles
}

\author{
Jonathan I. Matsui, Elizabeth C. Oesterle, Jennifer S. Stone, And Edwin W. Rubel \\ Virginia Merrill Bloedel Hearing Research Center and the Department of Otolaryngology-HNS, \\ University of Washington, Seattle, WA 98195 USA
}

Received: 17 December 1999; Accepted: 20 March 2000; Online publication: 13 July 2000

\begin{abstract}
Hair cell regeneration occurs spontaneously throughout life and following hair cell injury in the vestibular epithelia of mature birds and other nonmammalian vertebrates. We examined hair cell regeneration in post-hatch chick utricles that were cultured in media with or without the ototoxin, streptomycin, for various periods. The goal of our study was to characterize the dose- and time-dependent effects of streptomycin on hair cell loss and regeneration in vitro. Utricles that were cultured with streptomycin for 1 day displayed a dose-dependent loss of hair cells in spatial patterns and levels that were consistent with those observed in comparable experimental paradigms in vivo. Incorporation of the nucleotide analog bromodeoxyuridine (BrdU) demonstrated that supporting cell proliferation is decreased during the first day of culture in the presence of streptomycin, but it increases over time when cultures are subsequently placed in streptomycin-free media. Utricles cultured for 1 day with streptomycin followed by 2-4 more days without streptomycin had numerous bundles of immature stereocilia, suggesting that new hair cells were generated in vitro. We tested this hypothesis by culturing utricles with BrdU for 3 or 5 days and double-labeling them to detect BrdU and the hair cell-specific antigen, TuJ1. Numerous BrdU-positive/TuJ1-positive cells with phenotypic characteristics of immature hair cells were present in
\end{abstract}

Present address (JIM): Washington University, Central Institute for the Deaf, Fay and Carl Simons Center for Biology of Hearing and Deafness, St. Louis, MO 63110 USA.

Correspondence to: Dr. Edwin W. Rubel • Virginia Merrill Bloedel Hearing Research Center • Box $357923 \cdot$ University of Washington - Seattle, WA 98195-7293. Telephone: (206) 543-8360; fax: (206) 221-5685; email: rubel@u.washington.edu the cultures, and the number of such cells increased between 3 and 5 days in vitro, in a dose-dependent manner.

Keywords: hair cells, vestibular, chicken, tissue culture, differentiation, proliferation

\section{INTRODUCTION}

Hair cells are the mechanoreceptors of the auditory, vestibular, and lateral-line end organs that are involved in the detection of sound, balance, orientation, and head movements. Disease, aging, infection, and exposure to noise or ototoxic drugs cause hair cell loss in the inner ear. Birds and other nonmammalian species are capable of regenerating hair cells and thereby repairing their receptor epithelium such that function is regained (reviewed in Cotanche et al. 1994; Carey et al. 1996; Stone et al. 1998; Cotanche 1999; Smolders 1999). In contrast, damage to the mammalian inner ear results in permanent hearing and/or balance deficits. Insights gained from studying hair cell regeneration in nonmammalian species may shed light onto mechanisms that can be used to trigger hair cell regeneration in mammals.

In the mature vestibular epithelia of birds, hair cells die spontaneously and are continually replaced via mitosis throughout the life of the animal (Jørgensen 1991; Jørgensen and Mathiesen 1988; Roberson et al. 1992; Weisleder and Rubel 1993). Hair cell production in this system is highly upregulated over control levels when large numbers of hair cells are killed by experimental exposure to the ototoxic aminoglycoside antibiotic, streptomycin (Weisleder and Rubel 1992, 1993; 
Weisleder et al. 1995; Oesterle et al. 1993; Carey et al. 1996; Bhave et al. 1998). On the other hand, continual postembryonic production of hair cells does not occur in the auditory receptor epithelium, the basilar papilla, of birds (Ryals and Rubel 1988; Corwin and Cotanche 1988; Oesterle and Rubel 1993). However, restoration of the auditory hair cell population does occur after hair cell loss is experimentally induced by ototoxic drugs or intense noise (Cotanche 1987; Cruz et al. 1987; Corwin and Cotanche 1988; Ryals and Rubel 1988; Lippe et al., 1991). Regenerated hair cells in both the avian auditory and vestibular systems achieve sufficient function to restore balance and hearing function (for review, see Cotanche et al. 1994; Stone et al. 1998; Cotanche 1999; Smolders 1999). In birds, the progenitors to the new hair cells appear to be a subpopulation of the resident supporting cell population (Corwin and Cotanche 1988; Girod et al. 1989; Raphael 1992; Roberson et al. 1992; Hashino and Salvi 1993; Stone and Cotanche 1994; Tsue et al. 1994; Warchol and Corwin 1996). Recent studies also suggest that the mature mammalian vestibular epithelium has a limited capability for the mitotic replacement of hair cells (Warchol et al. 1993; Lambert 1994; Tanyeri et al. 1995; Yamashita and Oesterle 1995; Li and Forge 1997; Lopez et al. 1997; Zheng et al. 1997; Zheng and Gao 1997; Kuntz and Oesterle 1998).

Cell proliferation and hair cell regeneration occur in in vitro preparations of the hair cell epithelia of many nonmammalian species. In mature birds, new hair cells are formed in cultures of the utricle (e.g., Oesterle et al. 1993; Warchol and Corwin 1993) and the basilar papilla (Navaratnam et al. 1996; Stone et al. 1996). None of these studies, however, has provided an in-depth analysis of the extent of hair cell loss, mitotic activity, and hair cell replacement in culture.

This project had two objectives. First, we wished to develop and standardize an in vitro preparation of the avian utricle for studies of streptomycin-induced hair cell loss and of subsequent events leading to hair cell regeneration. Second, we sought to determine the extent to which newly produced cells in vitro display hair cell phenotypes by using a mitotic tracer in combination with a hair cell-specific marker.

Chick utricles were cultured in media supplemented with various concentrations of streptomycin. Some utricles were examined immediately after the streptomycin treatment (short-term cultures) to define the patterns and extent of hair cell loss, whereas other utricles were cultured in streptomycin-free media following the drug exposure (long-term cultures) to allow hair cell regeneration to occur. Hair cell loss was directly related to streptomycin concentration and was confined to the striolar region in short-term cultures but extended beyond the striolar region in long-term cultures. Sensory epithelial cell proliferation, as assessed by labeling with the nucleotide analog, bromodeoxyuridine (BrdU), decreased immediately after exposure to low and moderate doses of streptomycin and increased significantly by 1 day after removal of the drug. High doses of streptomycin inhibited supporting cell proliferation at all times. Scanning electron microscopy and the use of a cell proliferation tracer in combination with the hair cell-specific marker, TuJ1, demonstrated that many cells that are generated mitotically in culture goon to differentiate as hair cells.

Preliminary reports of portions of these data were presented previously (Matsui et al. 1997a,b).

\section{MATERIALS AND METHODS}

\section{Animals}

White Leghorn chickens (Gallus domesticus) were obtained from a local distributor ( $\mathrm{H} \& \mathrm{~N}$ International, Redmond, WA) and were housed in brooders with ample food and water in the University of Washington's animal care facility. All experimental protocols were reviewed and approved by the University of Washington Animal Care Committee and conform to NIH guidelines.

\section{Primary antibodies}

Mouse monoclonal anti-BrdU antibody was obtained from Becton Dickenson (San Jose, CA). Dr. Anthony Frankfurter (University of Virginia) generously donated mouse monoclonal TuJ1 antibody, and Dr. Guy Richardson (University of Sussex, UK) kindly provided mouse monoclonal antibody to hair cell antigen (HCA).

\section{Bromodeoxyuridine injections}

To assess the temporal progression of hair cell differentiation in utricles in vivo, normal 7-day-old chicks were given 2 intraperitoneal injections of BrdU (100 mg/ $\mathrm{kg}$ ), delivered 2 hours apart. Two hours, 2 days, or 4 days after the final BrdU injection, chicks were euthanized by sodium pentobarbital overdose $(100 \mathrm{mg} / \mathrm{kg}$; Anpro Pharmaceutical, Arcadia, CA) and decapitated. Seven- to 10-day-old post-hatch control chicks were also euthanized in the same manner. Utricles were surgically removed, fixed for 30 minutes with $4 \%$ paraformaldehyde in $0.1 \mathrm{M} \mathrm{Na} / \mathrm{K}$ phosphate buffer $(\mathrm{pH}$ 7.4), and rinsed in $0.1 \mathrm{M}$ phosphate-buffered saline (PBS). Otoconia were washed off with a pulse of PBS. 

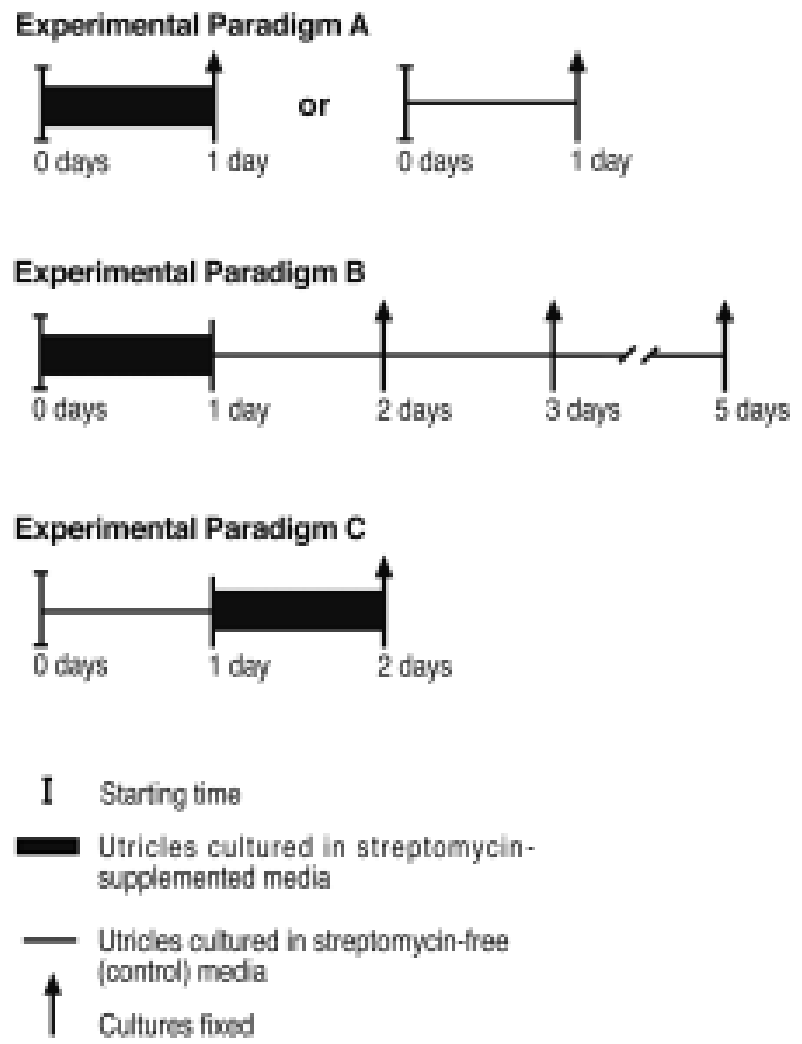

FIG. 1. Schematic of the experimental paradigms used in this study. See text for details.

\section{Organ culture techniques}

Seven- to 10-day-old posthatch chicks were decapitated, and the utricles were removed and cultured as organotypic explants using methods developed by Oesterle et al. (1993, 1997). Utricles were placed freefloating into 24-well tissue culture plates (Costar, Cambridge, MA) with $1.0 \mathrm{~mL}$ of Basal Medium Eagle (Sigma Chemical Co., St. Louis, MO) supplemented with 30\% Earle's balanced salt solution (Gibco/BRL, Gaithersburg, MD), $0.5 \%$ glucose (Sigma), and 5\% Fetal Bovine Serum (Gibco/BRL). Explants were incubated at $37^{\circ} \mathrm{C}$ in a humidified $5 \% \mathrm{CO}_{2}$-in-air incubator. An additional group of utricles, which we have termed the "in vivo" utricles, were not cultured; they were isolated and fixed immediately in $4 \%$ paraformaldehyde. These organs served as additional controls.

\section{Culture paradigms}

Three experimental paradigms were used (Fig. 1). To determine dose-response characteristics of druginduced hair cell damage and cell proliferation (Para$\operatorname{digm} \mathbf{A})$, utricles were incubated in culture media with or without streptomycin (at $0.078,0.16,1.2$, and 2.5 $\mathrm{mM}$; Sigma) for 1 day and then fixed. In some cultures 2'-bromo-5'-deoxyuridine (BrdU; $10 \mathrm{nM}$; Sigma), a nucleotide analog that is incorporated into DNA during the DNA synthesis (S) phase of the cell cycle, was added to culture media 3 hours prior to fixation. To examine cell proliferation and differentiation in longterm cultures (Paradigm B), utricles were incubated in streptomycin (at $0.078,0.16,1.2$, or $2.5 \mathrm{mM}$ ) for 1 day, washed 3 times with streptomycin-free (control) media, incubated in control media for another 1, 2, or 4 days (a cumulative equivalent of 2,3 , or 5 days in vitro, respectively), and then fixed. BrdU (10 nM) was added to the media 3 hours before fixation or was present throughout the entire culture period. In Paradigm C, utricles were cultured for 1 day in control media and transferred to streptomycin (at 0.078, 0.16, 1.2 , or $2.5 \mathrm{mM})$ for an additional day. $\mathrm{BrdU}(10 \mathrm{nM})$ was added to the media 3 hours prior to fixation. For paradigms A-C, control organs were prepared in parallel and processed identically to the experimental organs, except they were incubated in aminoglycosidefree media throughout the experiment. The number of organs tested for each experimental paradigm is indicated in the relevant figure captions.

\section{Tissue processing}

Scanning electron microscopy. To qualitatively assess the damage following streptomycin exposure, utricles from Paradigms A and B were processed for scanning electron microscopy (SEM). Utricles were fixed with $3.5 \%$ glutaraldehyde in $0.1 \mathrm{M} \mathrm{Na} / \mathrm{K}$ phosphate buffer (pH 7.4) and postfixed in osmium tetroxide $\left(1 \% \mathrm{OsO}_{4}\right.$ in PBS, pH 7.4). After otoconia removal, utricles were dehydrated in serial alcohols, critically point-dried in $\mathrm{CO}_{2}$, mounted onto aluminum stubs, sputter-coated with gold/palladium alloy (Anatech, Alexandria, VA), and examined with a JEOL JSM-6300F scanning electron microscope at $85,95,2000,3000$, or $4500 \mathrm{X}$ magnifications.

Bromodeoxyuridine immunohistochemistry. Utricles were fixed for $20 \mathrm{~min}$ with $4 \%$ paraformaldehyde in $0.1 \mathrm{M} \mathrm{Na} / \mathrm{K}$ phosphate buffer and rinsed with PBS. BrdU immunohistochemistry (Gratzner 1982) was modified from Stone and Cotanche (1994). All steps were carried out at room temperature with PBS washes between them, unless otherwise stated. Organs were treated with $2 \mathrm{~N} \mathrm{HCl}$ diluted in $0.1 \%$ Triton X-100/ PBS (Sigma) at $37^{\circ} \mathrm{C}$ for $30 \mathrm{~min}$. Tissue was placed in $0.5 \%$ hydrogen peroxide $\left(\mathrm{H}_{2} \mathrm{O}_{2}\right)$ in PBS for 15 min followed by $10 \%$ normal horse serum (Vector Laboratories Inc., Burlingame, CA) in $0.1 \%$ Triton X-100/ PBS $/ 1 \%$ bovine serum albumin (BSA; Sigma) for 20 min. Tissue was incubated overnight at $4^{\circ} \mathrm{C}$ in mouse anti-BrdU monoclonal antibody ( $1: 200$, in $0.1 \%$ Triton $\mathrm{X}-100 / \mathrm{PBS} / 1 \% \mathrm{BSA})$, incubated in biotinylated horse antimouse IgG antibody (1:200, in $0.1 \%$ Triton X-100/ PBS/1\% BSA; Vector Laboratories Inc.) for $30 \mathrm{~min}$, 
and placed in avidin-biotin-horseradish peroxidase complex (Vector Laboratories Inc.) for $45 \mathrm{~min}$. The tissue was rinsed in $0.05 \mathrm{M}$ Tris buffer ( $\mathrm{pH}$ 7.4), placed in diaminobenzadine $(\mathrm{DAB} ; 0.375 \mathrm{mg} / \mathrm{mL}$ in $0.05 \mathrm{M}$ Tris/ $0.3 \mathrm{mM} \mathrm{NiCl}$; Sigma) for $5 \mathrm{~min}$, followed by DAB plus $\mathrm{H}_{2} \mathrm{O}_{2}(0.375 \mathrm{mg} / \mathrm{mL}$ in $0.05 \mathrm{M}$ Tris/ $0.3 \mathrm{mM} \mathrm{NiCl} /$ $\left.0.01 \% \mathrm{H}_{2} \mathrm{O}_{2}\right)$ for another 3-5 min. Organs were mounted onto microscope slides using Glycergel mounting medium (DAKO Corporation, Carpinteria, CA), and coverslipped.

Tritiated-thymidine autoradiography. In a small subset of cultures, we assayed cell proliferation with $\left[{ }^{3} \mathrm{H}\right]$ thymidine $(1 \mu \mathrm{Ci} / \mathrm{mL}$ of $5.0 \mathrm{Ci} / \mathrm{mM}$; Amersham, Arlington Heights, IL) to confirm the efficacy of BrdU incorporation and immunolabeling. Paradigm A was used and $\left[{ }^{3} \mathrm{H}\right]$ thymidine was added to the cultures in replacement of BrdU. After culturing, explants were fixed and processed for section autoradiography as described in Oesterle et al. (1993).

Immunofluorescence to detect regenerating hair cells. Whole-mount utricles were either double-labeled to detect BrdU and class III $\beta$-tubulin ( $\beta$-tubulin III) using the TuJ1 antibody, or triple-labeled to detect BrdU, $\beta$-tubulin III, and hair cell antigen (HCA), using immunofluorescence techniques. All steps were carried out at room temperature with PBS washes between them, unless otherwise stated. The tissue was incubated for 10 min in 10\% normal horse serum in $0.05 \%$ Triton X-100/PBS to block nonspecific IgG binding followed by TuJ1 antibody (1:1000, in $0.1 \%$ Triton X$100 / \mathrm{PBS}$ ) overnight at $4^{\circ} \mathrm{C}$. TuJ1 labeling was detected using BODIPY/fluorescein isothiocyanate (FITC)-conjugated IgG (1:300, in $0.05 \%$ Triton X-100/PBS; Molecular Probes, Eugene, OR) for $1 \mathrm{~h}$. Utricles were postfixed with $4 \%$ paraformaldehyde for $30 \mathrm{~min}$, rinsed, and placed into $2 \mathrm{~N} \mathrm{HCl}$ at room temperature for $1 \mathrm{~h}$. Tissue was incubated in mouse anti-BrdU monoclonal antibody (1:300, in $0.05 \%$ Triton X-100/ PBS) for $2 \mathrm{~h}$, followed by lissamine rhodamine-conjugated IgG (1:300, in $0.05 \%$ Triton X-100/PBS; Jackson ImmunoResearch Labs, Westgrove, PA) for $1 \mathrm{~h}$. This double-labeling method was modified from Memberg and Hall (1995). Organs were mounted onto slides using Vectashield mounting medium (Vector Laboratories Inc.) and coverslipped.

In some experiments, a third antibody, anti-HCA, was used in conjunction with BrdU and TuJ1 labeling. Anti-HCA was added after TuJ1 but before the antiBrdU antibody labeling. Utricles were treated with $10 \%$ normal horse serum for $10 \mathrm{~min}$ and incubated overnight at $4^{\circ} \mathrm{C}$ with anti-HCA (1:300, in $0.05 \%$ Triton $\mathrm{X}-100 / \mathrm{PBS})$. Organs were placed in Cy-5-conjugated IgG (1:300, in $0.05 \%$ Triton X-100/PBS; Jackson ImmunoResearch Labs) for $1 \mathrm{~h}$.

\section{Data analysis}

Counts of BrdU-labeled cells. The number of BrdUlabeled sensory epithelial (SE) cells was counted in whole-mount preparations of the utricular maculae using light microscopy. The location of each BrdUlabeled SE cell was mapped onto an enlarged outline of each utricular macula drawn to scale using the Eutectics Neuron Tracing System (ENTS, Sun Microsystems, Raleigh, NC) at a final magnification of 400X. BrdU-positive nuclei were easily detected by their dark brown nuclear staining. Great care was taken to count only BrdU-labeled nuclei that were situated between the top of the $\mathrm{SE}$ and the basement membrane. The number of BrdU-labeled SE cells per $\mathrm{mm}^{2}$ of SE was calculated for each explant.

To verify the reproducibility of the analysis technique, 6 organs from each streptomycin concentration and 6 control organs (a total of 24 organs) underwent an additional blinded analysis by a second investigator. No significant differences in the resulting cell counts were found between observers $(p$ $>0.10)$.

Counts of hair cells in plastic sections. Utricles were dehydrated in a graded ethanol series followed by propylene oxide and embedded in Spurr's resin (Polyscience, Warrington, PA). Utricles were oriented randomly with respect to the striolar region. Serial semi-thin $(3 \mu \mathrm{m})$ sections were cut through half of the organ and mounted onto acid-washed, chrome alum-subbed slides. Sections were analyzed using light microscopy and NIH Image, an image processing program. In each organ, one section was chosen randomly from every 10 serial sections (at $30-\mu \mathrm{m}$ intervals) through half of the organ. This procedure resulted in the analysis of 12-16 sections per organ. The length of the vestibular SE was quantified for each section using a 40X objective and NIH Image 1.60 (developed at the U.S. National Institutes of Health, Bethesda, $\mathrm{MD}$, and available from the Internet by anonymous FTP from zippy.nimh.nih.gov or on floppy disk from the National Technical Information Service, Springfield, VA, part number PB95-500195GEI). Hair cell numbers were expressed as a function of SE linear density (number of hair cells/100 $\mu \mathrm{m} \mathrm{SE}$ ). Hair cells were distinguished easily from other cell types in the utricular macula (see Results). A cell was counted as a hair cell if it had an identifiable cuticular plate and its cell body did not contact the basal lamina. Type I and Type II hair cells, which normally are identified by the morphology of their innervation (Wersäll 1956; Jørgensen and Christensen 1989), could not be distinguished since the neural endings to the hair cells retract and degenerate in vitro (Oesterle et al. 1993).

Counts of $\left[{ }^{3} \mathrm{H}\right]$-thymidine-labeled cells. Autoradiographic sections were processed and analyzed to detect 
the presence of $\left[{ }^{3} \mathrm{H}\right]$-thymidine-labeled nuclei in the utricular SE using Method 1 in Oesterle et al. (1997), except that one autoradiographic section was chosen randomly from every ten serial sections through half the organ. The number of $\left[{ }^{3} \mathrm{H}\right]$-thymidine-labeled cells per $100 \mu \mathrm{m}$ of SE was computed for each section, and values for individual sections were averaged to yield a mean linear density value for each explant.

Identification of newly regenerated hair cells. Utricles that were double-labeled to detect BrdU and TuJ1 or triple-labeled to detect $\mathrm{BrdU}$, TuJ1, and HCA were examined with a BioRad MRC 1024 confocal laser scanning microscope. Digital images were generated from $\mathrm{Z}$ series $(0.5-1 \mu \mathrm{m}$ steps oriented parallel to the lumen) through the SE using Laser Sharp (BioRad, Hercules, CA) at 60X. Images were processed and analyzed using NIH Image and Photoshop 3.0.5 (Adobe, Mountain View, CA) and printed with a Phaser IISDX dye-sublimation printer (Tektronix, Beaverton, OR). The average number of cells that were either singlelabeled for BrdU or double-labeled for BrdU and TuJ1 per $\mu \mathrm{m}^{2}$ of SE was quantified within eight $100 \mu \mathrm{m} \times$ $100 \mu \mathrm{m}$ randomly chosen regions from each of 3-4 utricles. A transparency was placed onto the monitor, and each double-labeled cell was counted by marking it on the transparency. After sampling the area, the region was photobleached, thus preventing the area from being double counted.

\section{Statistical analysis}

Quantitative data from hair cell counts, BrdU labeling, $\left[{ }^{3} \mathrm{H}\right]$-thymidine labeling, and double-labeling (BrdU/ $\mathrm{TuJ1}$ ) experiments were subjected to either an unpaired Student's T-test using StatView 4.0 (Abacus Concepts, Berkeley, CA), or a one-factorial or twofactorial analysis of variance (ANOVA) using the SuperANOVA software package (Abacus Concepts). Post hoc comparisons, when appropriate, used the Tukey-Kramer, Sheffe's, or Fisher's PLSD test.

\section{RESULTS}

\section{Morphology of in vivo utricles}

The structural organization of the avian utricle is similar to that of the mammalian utricle and consists of three layers (Fig. 2). The deepest layer (the stroma) is a loose connective tissue that is penetrated by nerves. The intermediate layer is a thin basement membrane, the basal lamina. The superficial layer, the sensory epithelium (SE), consists of hair cells, supporting cells, and a few resident leukocytes (Bhave et al. 1998). Supporting cell nuclei reside near the basal lamina. Supporting cell nuclei near the $\mathrm{M}$ phase (mitosis) of the

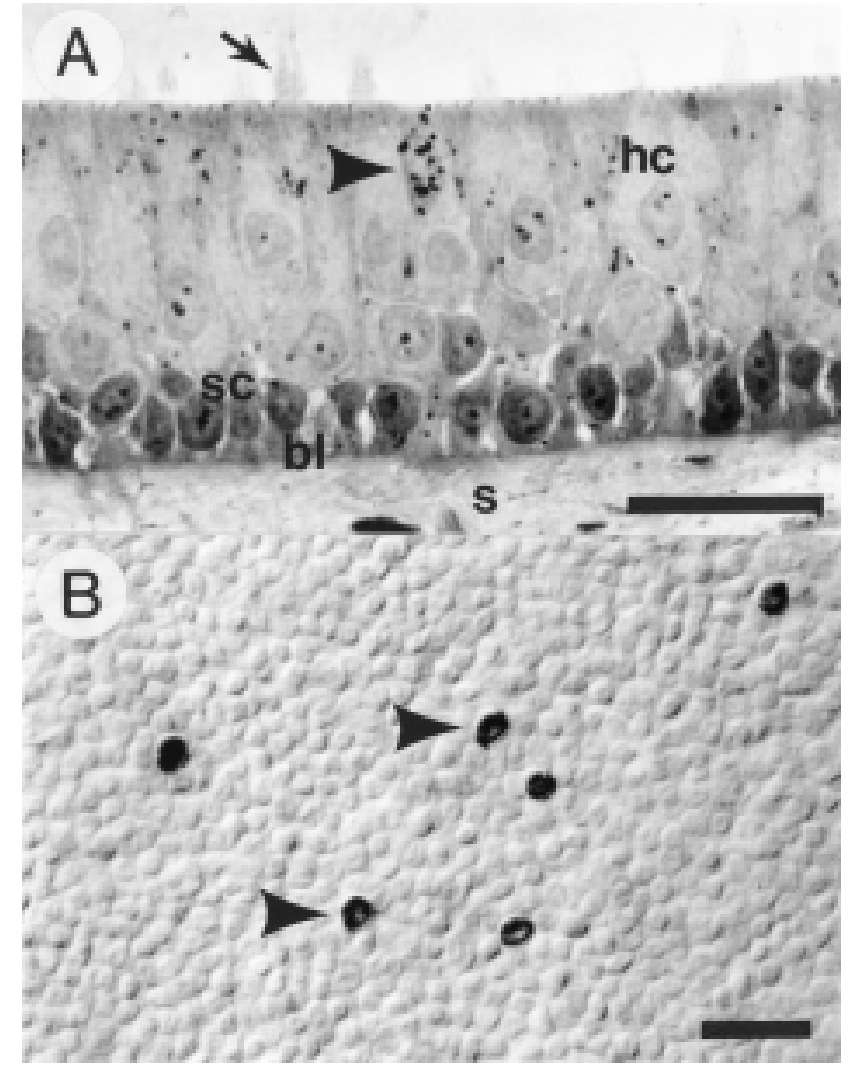

FIG. 2. Normal chicken utricular maculae grown in culture for 2 days and labeled with the mitotic tracers. (A) Autoradiograph showing a $\left[{ }^{3} \mathrm{H}\right]$-thymidine-labeled nucleus (arrowhead) in a cross section from a control utricle. The basal lamina (bl) separates the stroma (s) from the supporting cells (sc), which span the entire sensory epithelium and have basally located nuclei. Hair cells (hc) reside near the lumenal surface, have apical stereocilia (arrow), and their nuclei are located toward the lumen. (B) Surface view of a control wholemounted utricular macula showing BrdU-labeled nuclei (arrowheads) in the SE (Paradigm A). The plane of focus is at the level of the supporting cell nuclei. Scale bars $=20 \mu \mathrm{m}$.

cell cycle and hair cell nuclei are located close to the lumen (Raphael and Altschuler 1992; Katayama and Corwin 1993; Stone and Cotanche 1994; Tsue et al. 1994).

Vestibular hair cells are identified by their structural features (cuticular plate, stereocilia, and kinocilium) and the location of their nuclei near the lumenal surface. Two types of hair cells, Type I and Type II, are present in the avian utricular macula. Type I hair cells are pear-shaped and enclosed by a neural calyx. Type II hair cells have an elongated cylindrical appearance, and their basal surface contacts several bouton-type nerve endings. Type I hair cells are predominantly located in the lateral, "C-shaped" striolar region of the utricular macula, whereas Type II hair cells are generally found in the extrastriolar regions. Previous in vivo studies in the avian ear have shown that Type I hair cells are more susceptible than Type II hair cells 

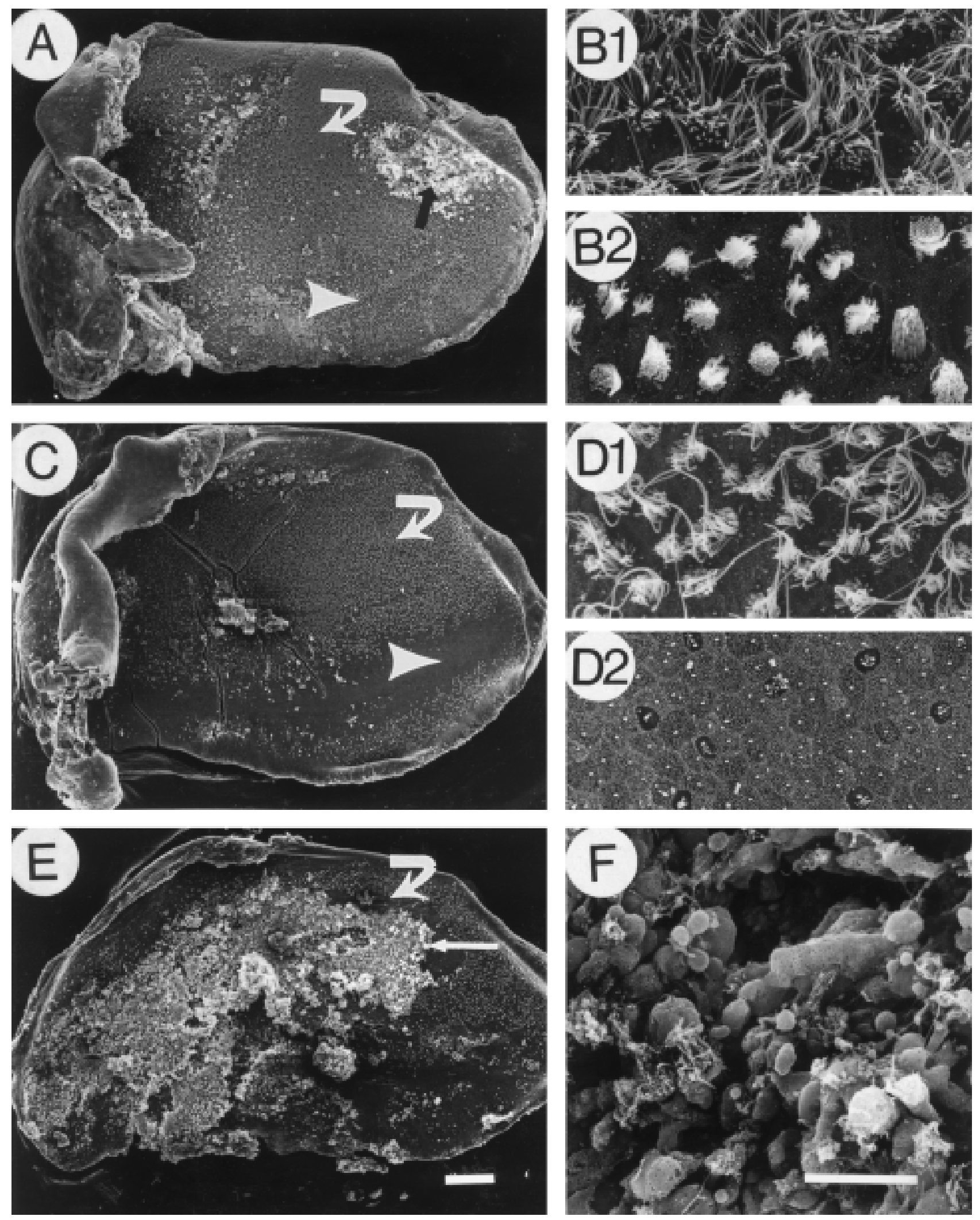

FIG. 3. Scanning electron micrographs of utricles after 1 day in vitro with control media $(\mathbf{A}, \mathbf{B})$ or media containing streptomycin (0.078 or $1.2 \mathrm{mM})(\mathbf{C}-\mathbf{F})$ (Paradigm A). In $\mathbf{A}, \mathbf{C}$, and $\mathbf{E}$, white curved arrows indicate extrastriolar areas, whereas white arrowheads point to striolar regions. (A) The lumenal surface of the cultured utricular macula appears normal in organs incubated in control media. The bright white area (black arrow) is otoconial debris. Higher magnifications of extrastriolar and striolar regions are shown in B1 and B2, respectively. $(\mathbf{C})$ Hair cell damage is predominantly localized to the striolar region (white arrowhead) at low streptomycin concentrations $(0.078 \mathrm{mM})$. As shown in higher magnifications of the extrastriolar

(D1) and striolar (D2) regions, stereociliary bundles are preserved in the extrastriolar region (D1), but extensive stereociliary loss is evident in the striolar region (D2). Some small immature stereociliary bundles are apparent in the striolar region. (E) Extensive stereocilia loss occurs throughout the extrastriolar and striolar regions with exposure to 1.2 $\mathrm{mM}$ streptomycin. The bright white areas (straight white arrow) are dead, extruded hair cells, not otoconial debris. A higher magnification of this damaged area is shown in $\mathbf{F} . n=3-4$ utricles per concentration per run; 2 runs were conducted. Scale bars in $\mathbf{A}, \mathbf{C}, \mathbf{E}=100 \mu \mathrm{m}$; in $\mathbf{B}, \mathbf{D}, \mathbf{F}=10 \mu \mathrm{m}$. 
to aminoglycoside-induced damage (Oesterle et al. 1993; Weisleder and Rubel 1993).

\section{Streptomycin-induced hair cell loss}

To characterize the pattern of hair cell loss induced by streptomycin, utricles were incubated in streptomycinfree media (control organs) or streptomycin-supplemented media (at $0.078,0.16,1.2$, or $2.5 \mathrm{mM}$ ) for 1 day and then examined using SEM (Paradigm A; Fig. 3). Little to no hair cell death was observed in control organs (Fig. 3A) in either the extrastriolar (Fig. 3B1) or striolar (Fig. 3B2) regions. Cultured control organs resemble organs that are harvested from the chick and fixed immediately (data not shown). In contrast, hair cell loss was apparent in utricles cultured with streptomycin, at all concentrations studied. At a low streptomycin concentration $(0.078 \mathrm{mM}$, Fig. $3 \mathrm{C}, \mathrm{D})$, relatively normal numbers of stereociliary bundles were present in extrastriolar regions (Fig. 3D1), but few stereociliary bundles remained in the striolar region (Fig. 3C, D2). At a higher streptomycin concentration (1.2 mM, Fig. $3 \mathrm{E}, \mathrm{F})$, all regions of the $\mathrm{SE}$ were covered with dead, extruded cells.

To quantify the effect of streptomycin dose on hair cell density, additional utricles were cultured according to Paradigm A, embedded in plastic, sectioned, stained, and the numbers of hair cells were determined. For comparison, utricles were also removed from normal, undamaged control chicks and fixed immediately ("in vivo" utricles); otherwise, in vivo organs were processed identically as cultured organs. The results of this analysis are shown in Figure 4. Hair cell densities in utricles that were cultured in control media (control utricles; 0.00 streptomycin in Fig. 4) were significantly lower than the densities found in in vivo organs $(p<0.01$; Fig. 4$)$. At all streptomycin concentrations studied, significantly fewer hair cells were present in drug-treated utricles than in control or in vivo utricles (a $41-88 \%$ decrease) $(p<0.01$; Fig. 4). Cultures that were treated with streptomycin at 1.2 or $2.5 \mathrm{mM}$ had significantly fewer hair cells $(p<0.01)$ than those treated with $0.078 \mathrm{mM}$ streptomycin (Fig. 4).

To study the regenerative capabilities of the cultured vestibular SE, utricles were cultured for 1 day in media with streptomycin and then transferred to streptomycin-free media for an additional 2 or 4 days (a total of 3 or 5 days in vitro; Paradigm B). As controls, organs were cultured in streptomycin-free media for 3 or 5 days. In 3-day control cultures, hair cell stereocilia bundles appeared morphologically similar to those seen in in vivo organs, and lesioned regions were not detectable (Fig. 5A, B). In contrast, a defined lesion

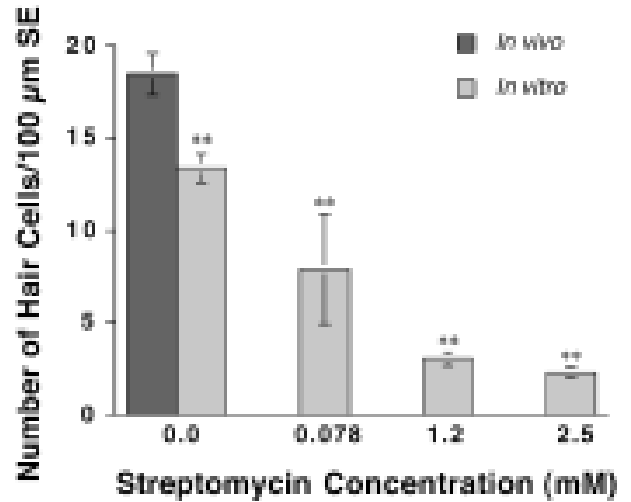

FIG. 4. Mean linear hair cell densities following a 1-day incubation in control or streptomycin-supplemented media (Paradigm A). Data are also included from the in vivo animals. Shown are the mean numbers of hair cells per $100 \mu \mathrm{m}$ of sensory epithelium (SE) \pm S.E.M. Hair cell numbers in control cultures differed significantly from in vivo organs $(p<0.01)$. All streptomycin concentrations induced significant hair cell death. For streptomycin-exposed organs, double asterisks indicate significantly less hair cells than cultured control organs $(p<0.01)$. For control cultures, double asterisk indicates significant difference from the in vivo organs $(p<0.01) . n=3-4$ organs per concentration per run; 2 runs were conducted.

consisting of an area missing numerous mature stereocilia bundles was seen in the striolar region of utricles that were cultured in $0.078 \mathrm{mM}$ streptomycin for 1 day and then incubated in control media for 2 more days (Paradigm B) (Fig. 5C). Three-day cultures that were incubated with $1.2 \mathrm{mM}$ streptomycin were almost completely devoid of mature stereocilia bundles throughout the SE (Fig. 5E, F). Lesions in the drugdamaged 3-day cultures generally resembled in size and in location the lesions from drug-damaged 1-day cultures (Paradigm A). Occasional bundles of short, immature stereocilia were also detected in the striolar regions of drug-damaged and control cultures at 3 days (Fig. 5D, F).

In 5-day control cultures, extensive hair cell death was apparent in both the striolar and extrastriolar regions (Fig. 6A, B). In cultures treated with 0.078 $\mathrm{mM}$ streptomycin, the lesion covered a greater area than in comparable experimental cultures at 1 and 3 days (Fig. 6C, D). In 5-day cultures treated with 1.2 $\mathrm{mM}$ streptomycin, mature stereocilia bundles were conspicuously absent from the entire SE. We detected greater numbers of immature stereocilia bundles in the striolar region of 5-day cultures than in 3-day cultures (Fig. 5D, F; Fig. 6D, F) (Figs. 5D, F and 6D, F). Further, the small stereocilia bundles appeared relatively more developed at 5 days than at 3 days; they appeared longer, but they still lacked the large kinocilium and stereotypical "staircase" pattern (Fig. 6F inset). 

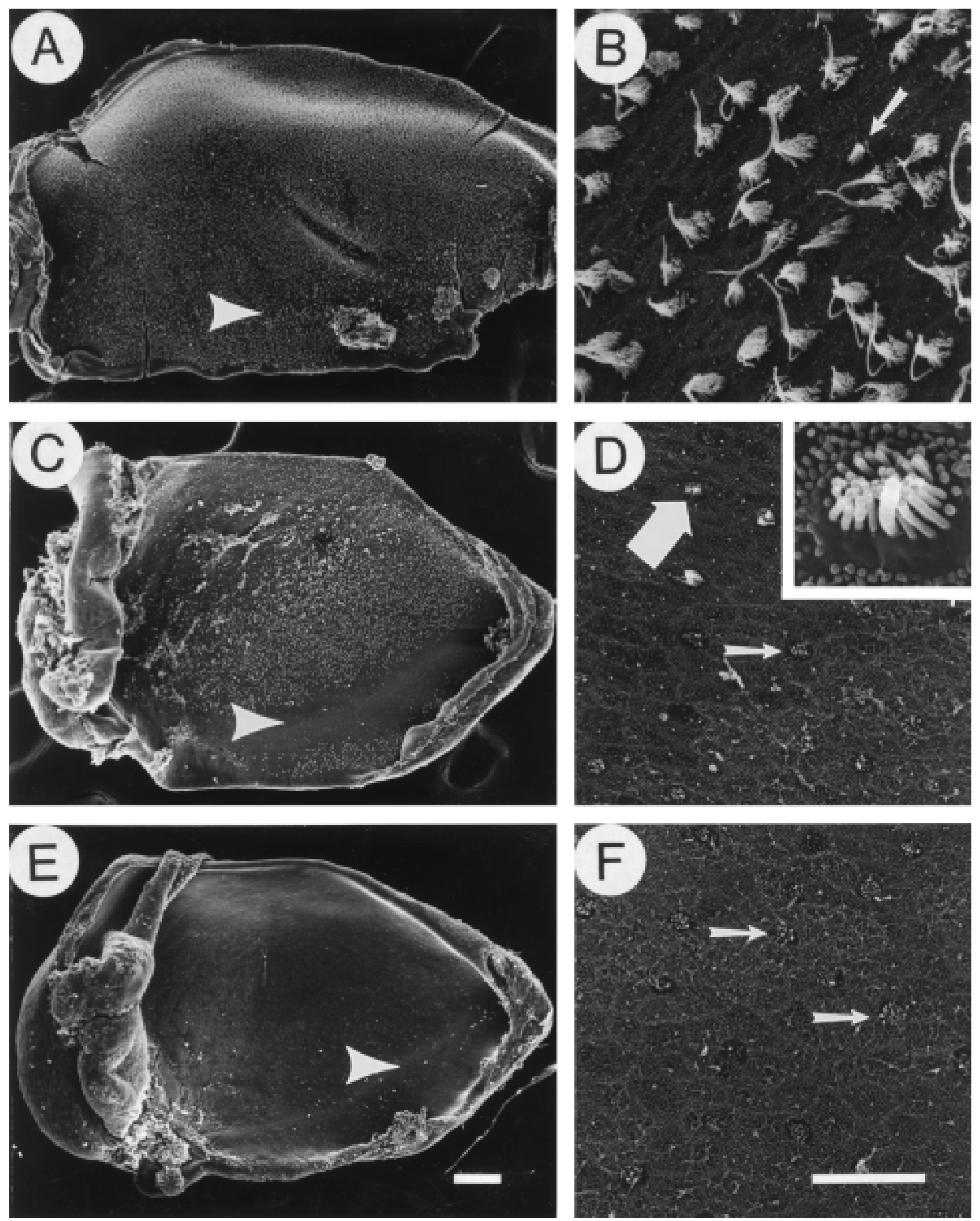

FIG. 5. SEMs of utricles grown in vitro for 3 days (Paradigm B). Utricles were incubated in control media for 3 days $(\mathbf{A}, \mathbf{B})$ or in streptomycin-supplemented media $(0.078$ or $1.2 \mathrm{mM}$ ) for 1 day then in control media for 2 days (total of 3 days in vitro) $(\mathbf{C}-\mathbf{F})$. Arrowheads in $\mathbf{A}, \mathbf{C}$, and $\mathbf{E}$ indicate the striolar regions that are shown at higher magnification in $\mathbf{B}, \mathbf{D}$, and $\mathbf{F}$. (A) In organs cultured in control mediacontrol organs-stereocilia loss is not evident and stereocilia appear normal. (C) Following exposure to $0.078 \mathrm{mM}$ streptomycin, the striolar region is largely devoid of hair cell stereocilia bundles. (E) Follow- ing exposure to $1.2 \mathrm{mM}$ streptomycin, stereocilia loss is apparent in both the striolar and extrastriolar regions of the utricular macula. (D, F) Immature hair cell stereocilia bundles (arrows) are present in the striolar region of streptomycin-damaged utricular maculas. Immature bundles are also apparent among the mature stereocilia bundles in control cultures (B). A higher magnification of an immature hair cell stereocilia bundle (large arrow) is shown in the inset of D. $n=3-4$ utricles per concentration per run; 2 runs were conducted. Scale bars in $\mathbf{A}, \mathbf{C}, \mathbf{E}=100 \mu \mathrm{m}$; in $\mathbf{B}, \mathbf{D}, \mathbf{F}=10 \mu \mathrm{m}$. 

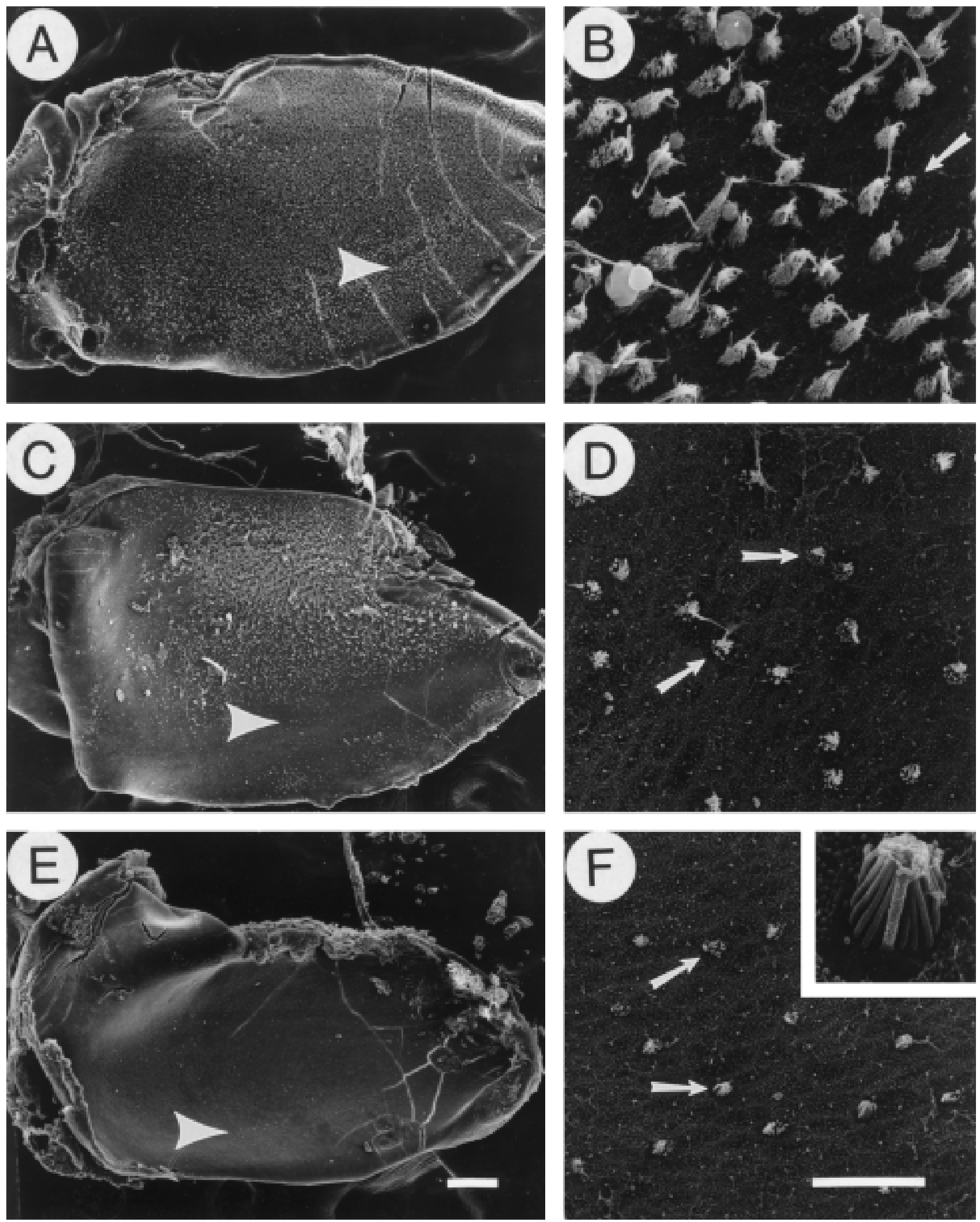

FIG. 6. SEMs of utricles after 5 days in vitro (Paradigm B). Utricles were incubated in control media (A, B) or streptomycin-supplemented media $(0.078$ or $1.2 \mathrm{mM})$ for 1 day $(\mathbf{C}-\mathbf{F})$, washed with control media and incubated 4 additional days in control media (a total of 5 days in vitro). Arrowheads in $\mathbf{A}, \mathbf{C}$, and $\mathbf{E}$ indicate the striolar region that is also shown at a higher magnification in $\mathbf{B}, \mathbf{D}$, and $\mathbf{F}$. (A) In organs cultured in control media, some stereocilia loss is apparent throughout the SE at 5 days in vitro and some hair cell blebbing can be seen. (C) Following exposure to $0.078 \mathrm{mM}$ streptomycin, the striolar region is devoid of mature hair cell stereociliary bundles, and there is also loss of stereocilia bundles in the extrastriolar regions. (E) Following exposure to $1.2 \mathrm{mM}$ streptomycin, the entire $\mathrm{SE}$ is devoid of mature stereocilia. (B, D, F) Immature hair cell stereocilia are evident in the striolar region (arrows). A higher magnification of an immature hair cell bundle is shown in the inset in $\mathbf{F} . n=8$ utricles per concentration from a total of 2 runs. Scale bars in $\mathbf{A}, \mathbf{C}, \mathbf{E}=100 \mu \mathrm{m}$; in $\mathbf{B}, \mathbf{D}, \mathbf{F}$ $=10 \mu \mathrm{m}$. 


\section{Supporting cell proliferation}

We opted to use BrdU as a proliferation marker to assess mitotic activity in the majority of the organotypic cultures, rather than $\left[{ }^{3} \mathrm{H}\right]$-thymidine, because we wished to examine the three-dimensional relationship of dividing cells in whole-mounted tissue and to combine BrdU immunolabeling with immunolabeling for hair cell-specific proteins (see below). In most cases, BrdU was added to culture media for $3 \mathrm{~h}$, and utricles were fixed immediately after the 3-h pulse and processed for BrdU immunohistochemistry (Gratzner 1982). In a few cultures, however, BrdU was replaced with $\left[{ }^{3} \mathrm{H}\right]$-thymidine, which we have used extensively in previous in vitro experiments (e.g., Oesterle et al. 1993 ; 1997), in order to confirm the efficacy of BrdU incorporation and immunolabeling for this study. The numbers of $\left[{ }^{3} \mathrm{H}\right]$-thymidine-labeled SE cells and the changes in $\left[{ }^{3} \mathrm{H}\right]$-thymidine labeling induced by the addition of streptomycin (data not shown) strongly resembled those seen with $\mathrm{BrdU}$. The BrdU findings are described in detail below.

BrdU-labeled SE cells were detected in all cultured organs examined (Fig. 2B). For Paradigms A and B, the locations of each BrdU-labeled SE cell were mapped onto a camera-lucida outline of the utricular macula using the Eutectics Neuron Tracing System (e.g., Fig. 7). This allowed us to compute the total number of labeled SE cells in each organ and to compare the spatial distributions of proliferation across organs. It also provided a "hard copy" of the data for each organ. Results of these experiments are summarized in Figure 7 and Figure 8. In both control and drug-treated cultures, the mitotic activity appeared to be most pronounced in the striolar region (Fig. 7). The density of BrdU-labeled SE cells in control organs remained relatively constant between 1 and 5 days in vitro ( $p>0.10$; Fig. 8). Utricles that were incubated in streptomycin-supplemented media for 1 day and then assessed for BrdU incorporation showed a marked decrease in the density of BrdU-labeled SE cells when compared with concordant control cultures $(p<0.01)$. In contrast, the density of BrdU-labeled SE cells increased significantly $(p<0.01)$ (3- to 4 fold) relative to controls 1 day after streptomycin removal; this is true for all streptomycin concentrations except $2.5 \mathrm{mM}$ (Fig. 8) ${ }^{1}$. As shown in Figure 8, the rate at which the mitotic levels returned to control values differed with streptomycin concentration. SE cell proliferation in utricles that were exposed to a low streptomycin concentration $(0.078 \mathrm{mM})$ were at or below control values by 3 days in vitro, whereas SE cell

\footnotetext{
${ }^{1}$ Similar findings were observed using a different ototoxic drug, neomycin sulfate $(1 \mathrm{mM})$. Like streptomycin, SE cell proliferation decreased in the presence of neomycin, peaked one day after neomycin removal, and began to decrease two days after neomycin removal.
}

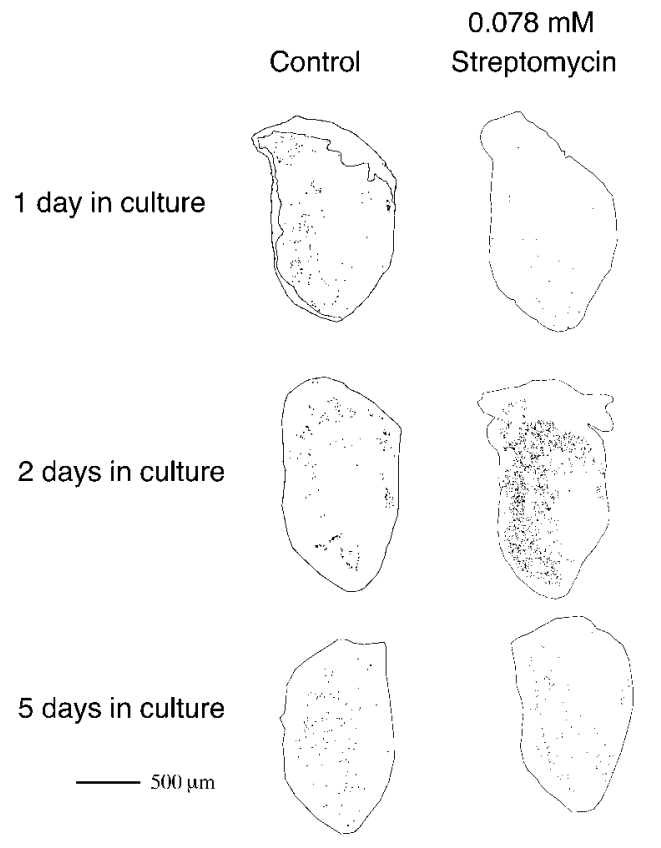

FIG. 7. Representative BrdU-immunostaining distribution maps for cultured chicken utricular macula specimens (Paradigms A and B). Control (left column) and $0.078 \mathrm{mM}$-streptomycin-treated utricles (right column) are shown at different times in vitro. All maculae are oriented with the striolar region along the left side of the organ. Numbers of BrdU-labeled SE cells remain relatively constant in control cultures at all time points examined. BrdU- labeled cells appear more concentrated in the striolar regions of the control cultures. In utricles exposed to $0.078 \mathrm{mM}$ streptomycin for 1 day, SE cell proliferation is markedly reduced with respect to the concordant control cultures. One day following streptomycin removal (equivalent to 2 days in culture), BrdU-labeled SE cells are increased relative to control cultures, and the labeled cells are more abundant in the striolar region. By four days following streptomycin removal (equivalent to 5 days in culture), cellular proliferation decreases to near control levels.

proliferation in utricles exposed to higher streptomycin concentrations $(0.16,1.2 \mathrm{mM})$ remained significantly higher than controls by 3 days $(p<0.01)$ and then returned to control levels by 5 days.

The presence of streptomycin in culture media significantly decreased the density of BrdU-labeled SE cells, suggesting that aminoglycosides have an initial inhibitory effect on supporting cell proliferation. To determine if this result could be replicated after different times in culture, we performed experiments similar to those previously described above, except we altered the timing of the streptomycin exposure. Organs were cultured in control media for 1 day, then transferred to media supplemented with streptomycin for 1 additional day and fixed (Paradigm $\mathrm{C})$. Control utricles were cultured in control media for a total of 2 days. BrdU was added to all cultures $3 \mathrm{~h}$ prior to fixation. In this experiment, greater numbers of BrdUlabeled SE cells were seen in control cultures (193.7 BrdU-labeled cells $/ \mathrm{mm}^{2} \mathrm{SE} \pm 28.5 \mathrm{SEM} ; n=12$ ) than in utricles that were exposed to streptomycin $(0.078-$ 


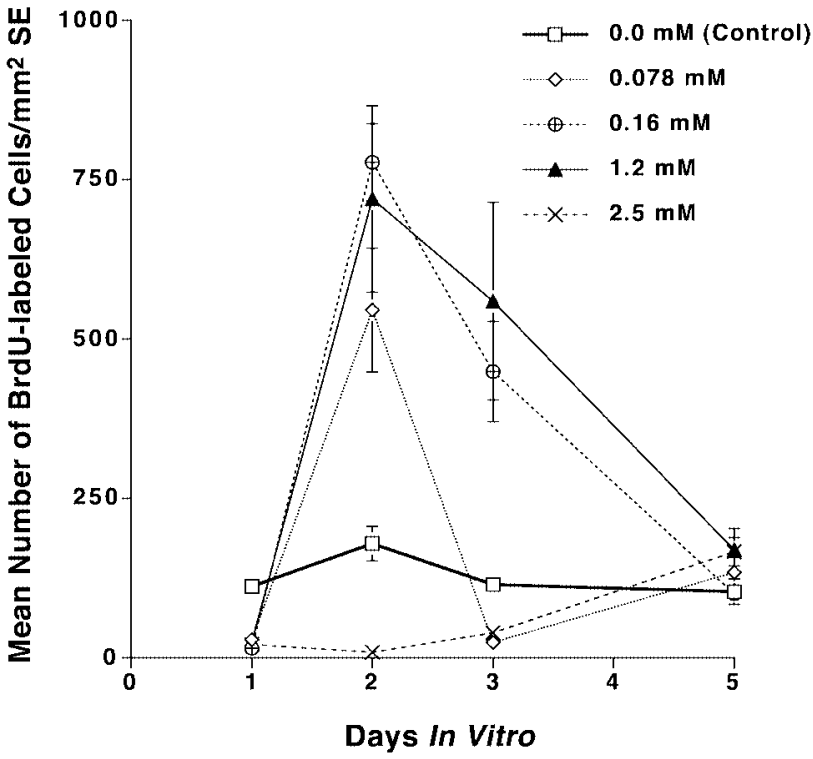

FIG. 8. Graph of the mean number of BrdU-labeled SE cells in control and streptomycin cultures at various times in vitro $(1,2,3$, and 5 days) (Paradigms $A$ and $B$ ). Data are expressed as the mean number of BrdU-labeled cells per $\mathrm{mm}^{2}$ ( \pm S.E.M.). In control cultures, the numbers of BrdU-labeled SE cells do not differ significantly over time. At 1 day in vitro (1 DIV), the numbers of BrdU-labeled SE cells are significantly lower in all streptomycin-treated cultures than in control cultures $(p<0.01)$. At 2 DIV $(1$ day after removing streptomycin), there is a two-to-three-fold increase in proliferation in some drug-treated cultures $(0.078-1.2 \mathrm{mM})$ relative to controls. However, organs exposed to $2.5 \mathrm{mM}$ streptomycin remained low or near control levels at all time points examined. At 3 DIV, cultures treated with $0.078 \mathrm{mM}$ streptomycin returned to near-control levels. In contrast, cultures exposed to higher concentrations of streptomycin (0.16 or $1.2 \mathrm{mM}$ ) maintained higher levels of mitotic activity at 3 DIV but showed decreased mitotic activity to near-control levels by 5 DIV. All values are significantly different from controls $(p<0.01)$, with the exception of 3 DIV $(0.078$ and $2.5 \mathrm{mM}$ ) and 5 DIV (all concentrations). $n=3-5$ utricles per concentration per time per run; $2-3$ runs were conducted.

$2.5 \mathrm{mM}$ ) (range of means $=27.2-45.4$ BrdU-labeled cells $/ \mathrm{mm}^{2} \mathrm{SE} ; n=8-11 /$ streptomycin concentration). All drug-exposed groups had significantly fewer labeled SE cells $(p<0.01)$ than utricles that were cultured without aminoglycosides. These findings support an initially antimitotic role for streptomycin in cultured utricular maculae.

\section{Hair cell differentiation in vivo}

The presence of immature stereocilia bundles in the 3-day cultures suggested that new, phenotypically appropriate hair cells were being generated in vitro. However, there are two other possible explanations. First, the immature-looking bundles may be a manifestation of a reparative response, whereby the damaged native hair cells build new stereocilia (Sobkowicz et al. 1996; Zheng et al. 1999). Second, the newly emerging stereocilia may be present on cells that are derived by a recently described nonmitotic mechanism of hair cell regeneration called direct transdifferentiation whereby supporting cells phenotypically convert into hair cells (Adler and Raphael 1996; Roberson et al. 1996; Baird et al. 1996; Steyger et al. 1997; Forge et al. 1998).

To determine whether newly generated cells acquire hair cell phenotypes in our cultures, we used two antibodies-TuJ1 and anti-hair-cell antigen (HCA) - in addition to BrdU to label new cells. TuJ1 is an antibody that binds class III $\beta$-tubulin in the cytoplasm (Lee et al. 1990; Easter et al. 1993) of very young avian hair cells during development (Molea et al. 1999) and regeneration (Stone et al. 1996; Stone and Rubel 2000). Anti-HCA binds a 275-kD protein that is present in chick hair cell stereocilia by embryonic day 6 (Bartolami et al. 1991; Goodyear and Richardson 1992, 1997; Goodyear et al. 1995) and that is detected in regenerating chick hair cells by approximately $48 \mathrm{~h}$ after they are reborn (Stone and Rubel 2000).

The specificity of these antibodies was first examined in vivo, in control utricles that were fixed immediately after dissection. It should be noted that our immunolabeling protocol leads to inevitable crossreactivity among the three sets of antibodies (antiBrdU, anti-HCA, and TuJ1), since they are all raised in mice. Despite false positive labeling, our results were interpretable for two reasons. First, the cellular compartmentalization of each antigen is distinct and nonoverlapping in mature cells as well as in differentiating ones: BrdU is nuclear, HCA is apical/stereociliary, and TuJ1 is cytoplasmic. Second, the relative intensities of each fluorophore were highest in the appropriate context (i.e., they were antigen-relative), and this difference was reflected in the 3-channel composites that we generated.

TuJ1 labeled all hair cells in the mature utricle, including Type I and Type II hair cells (Fig. 9A). Labeling was present throughout the hair cell cytoplasm, but not in the nucleus or the stereocilia. TuJ1 also labeled neural processes throughout the epithelium, but no labeling was observed in supporting cells (Fig. 9A). Some utricles were double-labeled to detect HCA as well as TuJ1. HCA was detected in hair cells in the striolar and extrastriolar regions, but not in supporting cells or neural processes. In hair cells, HCA was distributed throughout the stereocilia bundle, but it was not found in either the nucleus or the cytoplasm (Fig. 9B). Similar patterns of HCA labeling have been reported previously (Goodyear and Richardson 1992). HCA showed a one-to-one colocalization with $\mathrm{TuJ} 1$ in mature hair cells (Fig. 9B), as seen in developing hair cells (Molea et al. 1999). 
FIG. 9. Differentiation of utricular hair cells in vivo and in vitro. Antibodies to $\beta$-tubulin (TuJ1), hair cell antigen (HCA), and BrdU were used to selectively label newly differentiating hair cells in vivo (A-D) and in vitro $(\mathbf{E}, \mathbf{F})$. Projections of $Z$ series-confocal images are shown. (A) In the normal utricle, Tuj1 (blue: arrowhead) labels the cytoplasm of hair cells but not the intervening supporting cells. (B) In the normal utricle, HCA (red: arrow) labels stereocilia on TuJ1-positive hair cells (blue; arrowhead). (C) In the normal utricle at 2 days post-BrdU, TuJ1 (blue: arrowhead) is present in cells with BrdU-positive nuclei (green; thin arrow). (D) In the normal utricle at 4 days post-BrdU, HCA (pink; thick arrow) is expressed on the apical portion of some TuJ1-positive (blue; arrowhead) and BrdU-positive (green; thin arrow) cells. (E) At 3 days in vitro, TuJ1 (blue; arrowhead) is expressed in some cells with BrdU-positive nuclei (green; thin arrow). A utricle cultured without streptomycin is shown. (F) At 5 days in vitro, some TuJ1-positive (blue; arrowhead) and BrdU-positive (green; thin arrow) cells are also HCA-positive (pink; thick arrow). A utricle cultured with $0.078 \mathrm{mM}$ streptomycin is shown. Scale bar $=10 \mu \mathrm{m}$.
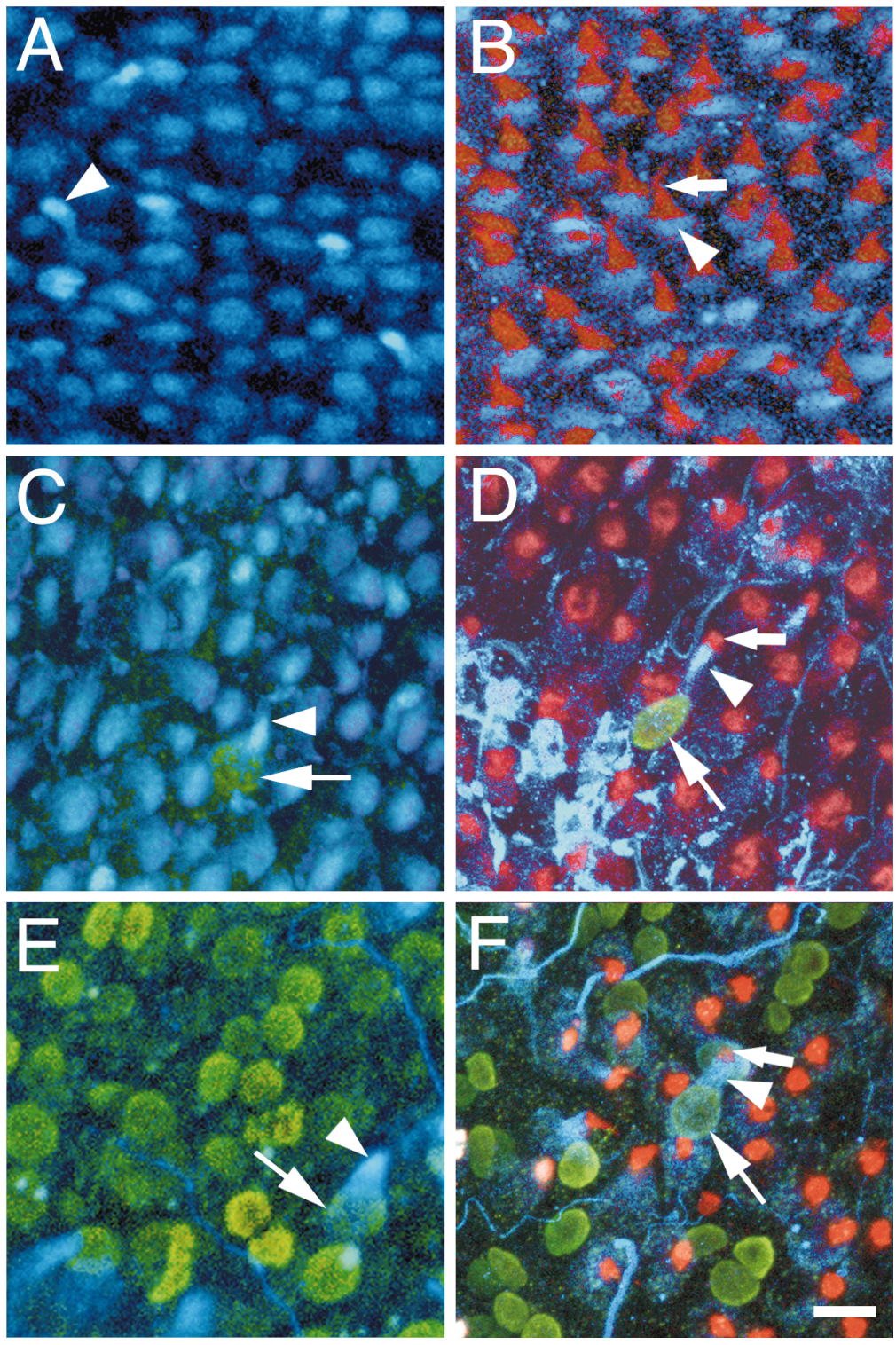

To determine when TuJ1 and HCA are expressed relative to $\mathrm{S}$ phase during spontaneous hair cell regeneration in vivo, control chicks were injected with BrdU and euthanized at $2 \mathrm{~h}, 2$ days, or 4 days after the injection. Utricles were dissected, fixed, and immunoreacted to detect BrdU, TuJ1, and HCA simultaneously.

Two hours following BrdU injection, few BrdUlabeled cells were observed, and all of the BrdUlabeled cells were TuJ1- and HCA-negative (data not shown). At 2 days post-BrdU injection, many BrdUlabeled cells were seen. Most BrdU-positive cells were TuJ1-negative and HCA-negative (Fig. 9C). The few BrdU-positive/TuJ1-positive cells that we did see were HCA-negative (Fig. 9C). BrdU-positive/TuJ1-positive cells at 2 days post-BrdU had elongated lumenal portions resembling the neck of a bottle, and they sometimes had close associations with neural processes. A similar hair cell phenotype has been described for developing and regenerating auditory hair cells (Whitehead and Morest 1985; Stone et al. 1996; Li and Forge 1997; Stone and Rubel 2000). Four days after BrdU injection, the number of cells that were positive for both TuJ1 and BrdU appeared to increase, and a few triple-labeled cells were identifiable (Fig. 9D). HCA labeling was most notable at the tip of the apical projections of TuJ1-positive cells.

Colabeling of TuJ1 and HCA in a few BrdU-positive cells with hair cell phenotypes demonstrates that the cells that were double-labeled for TuJ1 and BrdU were clearly differentiating into hair cells. This finding assured us that the combined use of $\mathrm{BrdU}$ and $\mathrm{TuJ} 1$ would be sufficient to assess the degree of hair cell regeneration that occurs in vitro, as described in the next section. Although these findings are strictly qualitative, they suggest that there is a temporal progression 
in hair cell differentiation during regeneration, whereby TuJ1 is expressed before HCA.

\section{Hair cell differentiation in vitro}

To determine the extent to which cells that are mitotically generated in culture go on to differentiate as hair cells, we performed triple-immunolabeling for $\mathrm{BrdU}$, $\mathrm{TuJ} 1$, and HCA on utricles that were cultured for 1 day with 0.078 or $1.2 \mathrm{mM}$ streptomycin and then maintained in streptomycin-free media for another 2 or 4 days. These periods corresponded to a total of 3 or 5 days in culture, respectively. Parallel control utricles were cultured in streptomycin-free media for the whole period. In all cultures, BrdU was present continuously to label all cells that are generated mitotically in vitro.

Triple-labeling in utricular cultures is shown in Figure $9(\mathrm{E}, \mathrm{F})$. BrdU-labeled nuclei were abundant in both 3-day and 5-day cultures. Some BrdU-positive cells were also labeled with $\mathrm{TuJ} 1$, and a few cells were triplelabeled (BrdU-positive/TuJ1-positive/HCA-positive). The morphologies of double-labeled (BrdU-positive/ $\mathrm{TuJ} 1$-positive) cells and triple-labeled cells were similar to those described for in vivo utricles (Fig. 9A-D), suggesting that hair cell differentiation occurs in culture in a similar manner as in vivo.

To quantify the densities of postmitotic cells in vitro, we systematically counted BrdU-positive cells, as well as BrdU-positive/TuJ1-positive cells, in eight randomly chosen regions of the utricular macula. We used TuJ1 as the marker for regenerated hair cells, rather than HCA, because it is expressed earlier during hair cell maturation. Further, TuJ1 is easier to visualize in that it is present throughout the hair cell cytoplasm, in contrast to the apically expressed HCA. We compared the number of BrdU-labeled cells and the number of double-labeled cells as a function of time in culture ( 3 days or 5 days) and as a function of aminoglycoside concentration $(0.0,0.078$, or $1.2 \mathrm{mM})$. Figure 10 presents data from this analysis. We found no significant difference in the density of BrdU-labeled cells between the two culture-time groups $(p>0.10)$. In contrast, there was a significant increase in the density of BrdUlabeled cells across drug concentrations $(p<0.005)$, and the number of double-labeled cells increased significantly with time in vitro $(p<0.001)$ and with drug concentration $(p<0.05)$. Between 3 and 5 days, the percentage of BrdU-labeled cells that are doublelabeled increased from $4 \%$ to $13 \%$ in control cultures, but this increase was not statistically significant $(p=$ 0.150 ). Between 3 and 5 days, the percentage of BrdUlabeled cells that were double-labeled increased from $1 \%$ to $21 \%$ in cultures with $0.078 \mathrm{mM}$ streptomycin, and from $1 \%$ to $25 \%$ in cultures with $1.2 \mathrm{mM}$ streptomycin; both of these increases are significant $(p<$
0.005). In 3-day cultures, the number of doublelabeled cells does not vary across streptomycin concentrations $(p>0.50)$, while in 5-day cultures, the number of double-labeled cells reliably covaried with drug concentration $(p<0.05)$. As expected from the above, there was also a significant interaction between culture duration and drug concentration $(p<0.05)$.

\section{DISCUSSION}

This study demonstrates the following: 1) A 1-day exposure to $0.078 \mathrm{mM}$ streptomycin kills approximately $40 \%$ of the hair cells in the cultured post-hatch chicken utricle; stronger streptomycin concentrations kill greater hair cell numbers; 2) cell proliferation is downregulated in cultured utricular maculae during aminoglycoside exposure and up-regulated by 1 day after the exposure; and 3) a subpopulation of proliferating cells in the cultured utricular macula differentiate as hair cells.

\section{Aminoglycosides kill vestibular hair cells in vitro}

The avian inner ear has become a model system with which to study hair cell regeneration. While there have been many studies using aminoglycosides to kill hair cells in cultured avian inner ear organs (Stone et al. 1996; Navaratnam et al. 1996; Kil et al. 1997; Hirose et al. 1997; Oesterle et al. 1996), little quantitative analysis of the hair cell loss has been performed. One goal of the present study was to carefully quantify the effects of different streptomycin doses and exposure times on hair cell numbers in cultured chicken utricles.

The amount of hair cell death induced by in vitro streptomycin at 1 day in vitro depends on the dose and length of the drug exposure. Exposure to low streptomycin concentrations (e.g., 0.078 and 0.16 $\mathrm{mM}$ ) kills hair cells primarily in the striolar region of the utricle, while exposure to higher concentrations causes increasing death among extrastriolar hair cells as well. The lesions resulting from streptomycin exposure in vitro are qualitatively and quantitatively similar to those reported following streptomycin injections in vivo in other studies. Weisleder and Rubel (1993) report the compete loss of Type I hair cells and 62\% loss of Type II hair cells in the chick ampulla by 1 day following 7 consecutive days of streptomycin injections, and Carey and colleagues (1996) describe the nearly complete $(97 \%)$ loss of Type I hair cells and $58 \%$ loss of Type II hair cells in the chick ampulla by 7 days following 5 consecutive days of streptomycin injections. In vivo aminoglycoside treatment causes similar lesions in the vestibular organs of rodents (Lindeman 1969; Kotecha and Richardson 1994; Forge et 
FIG. 10. Quantitation of BrdU-labeled and BrdU/Tul1labeled SE cells following streptomycin exposure in vitro (0.078 and $1.2 \mathrm{mM}$; Paradigm B). Light gray columns represent the number of BrdU-positive cells, while dark gray columns represent the number of BrdU-positive and TuJ1positive (double-labeled) cells. Labeled cells are plotted as mean number of cell $\mathrm{s} / \mathrm{mm}^{2}$ of SE ( \pm S.E.M.). That the absolute numbers of BrdU cells are 5-10 times the values seen in Figure 8 is due to the fact that $\mathrm{BrdU}$ was available during the entire culture period in this experiment. $n=3-4$ utricles per concentration per time point. al. 1993, 1998) and fish (Yan et al. 1991; Yan and Popper 1992). Further, adult guinea-pig utricles treated with neomycin in vitro show higher degrees of hair cell damage in the striolar region (Quint et al. 1998). The reason that Type I hair cells exhibit a higher susceptibility to aminoglycoside exposure is not known.

It is interesting to note that, while we could not detect a difference in the density of stereociliary bundles in control in vivo organs when compared with the in vitro cultured organs using SEM, a significant difference in hair cell number between these organs was revealed by our cross-sectional analysis. The discrepancy between the qualitative SEM results and the quantitative cross-sectional data may be a result of the relatively dense distribution of stereociliary bundles throughout the epithelium in each set of samples. In other words, it may be difficult to visually distinguish a difference in stereocilia number with SEM between the two sets of samples, while a systematic cross-sectional analysis is capable of elucidating variations in hair cell numbers.

\section{Cell proliferation in cultured utricular macula}

We examined cell proliferation in utricles that were cultured in media with and without streptomycin. In control cultures, we found that mitotic activity is most concentrated in the striolar region. This was a surprising observation, since proliferating supporting cells appear to be randomly distributed throughout the chick utricular macula in vivo (Roberson et al. 1992; Kil et al. 1997; Bhave et al. 1998). It is likely that our culture conditions were suboptimal for supporting complete hair cell survival and that some Type I hair cells or other hair cells in the striola died in vitro.

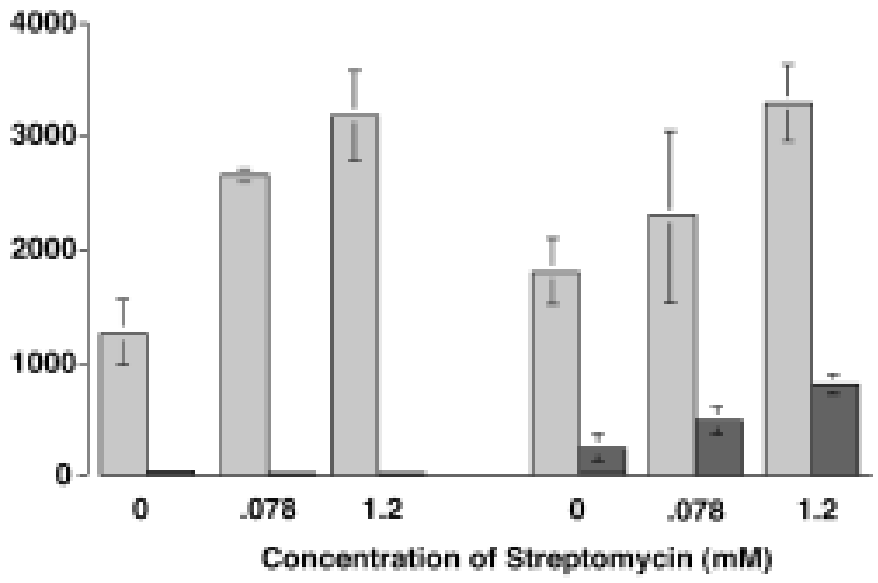

3 days in vitro $\quad 5$ days in vitro

Spontaneous death of mature hair cells in control cultures of inner ear end organs has been reported previously (Oesterle et al. 1993; Stone et al. 1996; Quint et al. 1998). It is likely that we see elevated levels of proliferation in the striola because Type I hair cells are more sensitive than Type II hair cells to the environmental stresses that occur from in vitro conditions.

Exposure to streptomycin in culture has a complex effect on supporting cell proliferation over time. Near the end of the exposure period (at 1 day in vitro), streptomycin (at all concentrations studied) causes a significant decrease in the number of proliferating supporting cells relative to that seen in control, unexposed cultures. With very high streptomycin concentrations, this decrease in proliferation is maintained for 2 additional days. However, with low streptomycin concentrations, supporting cell proliferation rates increase and peak by 2 days in vitro (1 day following the completion of the streptomycin exposure) and then decrease to reach control levels 2-3 days later.

We were surprised to find an initial inhibitory effect of streptomycin on supporting cell mitotic activity. To the best of our knowledge, this is the first report of aminoglycoside inhibition of supporting cell proliferation in either in vivo or in vitro conditions. Previous studies have examined levels of supporting cell proliferation after variable treatment and recovery periods, but not during the drug exposure. We are confident that the decrease in proliferation that we detected was not a result of a transient mitotic arrest caused by explantation into culture for the following reasons. We detected an average of $112 / \mathrm{mm}^{2}$ BrdU-positive supporting cells in our control, cultured utricles after a 3 -h BrdU pulse/fix at 1 day in vitro. A similar number of BrdU-positive supporting cells $\left(104 / \mathrm{mm}^{2}\right)$ has been documented in control utricles that were placed in 
culture and immediately pulsed with BrdU for $4 \mathrm{~h}$ then fixed (Oesterle et al. 1997). The number of BrdUpositive supporting cells obtained via the latter experiment reflects an estimate of the number of supporting cells in S phase at the time of culturing, which is in essence a snapshot of the steady-state proliferation level in the control utricle in vivo. These data point to an increase in supporting cell division during the first day in vitro relative to steady-state levels in vivo and suggest that there is no negative impact of the culturing process on supporting cell proliferation. Second, our results from experimental Paradigm C showed that streptomycin is capable of inhibiting supporting cell proliferation when added at 1 day in vitro rather than at the time of culturing. This finding suggests that putative changes in culture conditions between 1 and 2 days in vitro are not capable of affecting the streptomycin-induced inhibition of supporting cell proliferation. Based on these interpretations, we believe that the decrease in supporting cell proliferation at 1 day in vitro is most likely due to the effects of the streptomycin and not the culture conditions.

The mechanism by which streptomycin initially down-regulates mitotic activity in the utricular macula is unknown. Streptomycin may act directly on the cell cycle machinery of progenitor cells, or it may act indirectly. Aminoglycosides are known to enter and accumulate within inner-ear supporting cells in both the auditory and vestibular systems prior to the onset of hair cell death (Hayashida et al. 1985; de Groot et al. 1990; Hiel et al. 1993; Aran et al. 1995; Komeda and Raphael 1996). Their effects on supporting cells, however, have been poorly characterized. Another plausible reason for the down-regulation of supporting cell proliferation seen at early culture times is that supporting cells are mounting an injury response to the streptomycin effects. As a result of extensive hair cell loss, supporting cells may be attempting to reseal the reticular lamina, the junction between the surviving hair cells. This energy-intensive process may consequently restrict many supporting cells from entering the cell cycle at this time.

The reason for the resumption of supporting cell proliferation at 3 days in vitro is also unknown; however, it was not surprising. An increase in supporting cell proliferation over baseline levels has been documented previously in vivo (e.g., Lippe et al. 1991; Weisleder and Rubel 1993; Tsue et al. 1994; Bhave et al. 1995; Stone et al. 1996; Bhave et al. 1998) and in vitro (Navaratnam et al. 1996; Stone et al. 1996; Oesterle et al. 1996), and it is most likely due to the induction of hair cell loss. Numbers of proliferating cells were greatest in the striolar region, where maximal hair cell loss occurred. The highest levels of proliferation seen in our cultures occurred at 1 day after streptomycin removal; up to a four-fold increase was seen in drugdamaged vis-à-vis control cultures. The relative increase in mitotic activity that we saw in response to aminoglycoside exposure is in agreement with previous reports (Weisleder and Rubel 1993; Tsue et al. 1993; Bhave et al. 1998; Oesterle et al. 1996).

\section{Hair cells differentiate in organotypic explants}

Hair cell production in vivo occurs spontaneously in the avian vestibular organs (Jørgensen and Mathiesen 1989; Roberson et al. 1992) and in response to aminoglycoside treatment (Weisleder and Rubel 1993; Weisleder et al. 1995; Bhave et al. 1998; Stone and Rubel 1999). It has also been documented in vitro, in control utricles (Warchol and Corwin 1993) and in utricles that are cultured after in vivo aminoglycoside damage (Oesterle et al. 1993). Previous in vitro studies focused on SE cell proliferation; the ability of the proliferating cells to differentiate into hair cells has not been well characterized. To more fully characterize hair cell differentiation in vitro, we examined hair cell differentiation by using cell-specific markers that are useful for identifying newly generated hair cells before they form bundles of stereocilia (Stone et al. 1996; Stone and Rubel 2000). We combined the use of the hair cell-specific antibody TuJ1 with continuous BrdU labeling to show that some postmitotic cells generated in utricle cultures differentiate into hair cells. We felt this approach is important for two reasons. First, there is emerging evidence that hair cells can be formed via a nonmitotic process called direct transdifferentiation (Adler and Raphael 1996; Roberson et al. 1996; Baird et al. 1996; Steyger et al. 1997; Forge et al. 1998). Second, recent studies have shown that some damaged hair cells may be capable of repairing themselves. For example, hair cells in the cultured mouse organ of Corti can survive mechanical trauma and repair their cuticular plate and stereocilia bundle (Sobkowicz et al. 1995; Sobkowicz et al. 1996; Sobkowicz 1997). Further, in developing rat utricle exposed to gentamicin in vitro, partially damaged hair cells repair themselves without going through mitosis (Zheng et al. 1999).

We continuously provided BrdU in culture and analyzed only BrdU-positive cells to ensure that the cells we deemed as "regenerated" were newly formed by cell division. Since BrdU was present in the media for the entire culture period, BrdU-positive cells could be any of the following: postmitotic hair cells, postmitotic supporting cells, proliferative supporting cells, or proliferative leukocytes (Warchol 1997). Considering that the levels of proliferation at 3 days in vitro have significantly decreased relative to the peak levels of proliferation at 2 days in vitro, the majority of labeled cells in 3-day and 5-day cultures are probably postmitotic. 
We detected no significant difference in the number of BrdU-labeled cells between the two culture-time groups. One possible explanation of this finding is that a subpopulation of postmitotic regenerated cells dies in culture between 3 and 5 days. Such cell death could represent a continuation of the normal apoptotic program of the chick utricle (Jørgensen 1991; Kil et al. 1997), or it may signal that our culture system does not support the survival of postmitotic cells for long.

The number of double-labeled (BrdU-positive/ TuJ1-positive) cells increased significantly between 3 and 5 days in vitro. However, at 5 days in vitro, a large proportion of the BrdU-positive cells remains TuJ1negative. The relatively low level of hair cell regeneration that we see by 5 days in vitro probably reflects a delay in the time that it takes for some postmitotic cells to acquire a hair cell phenotype. We have shown in the undamaged utricle in vivo that it can take as little as 2 days for postmitotic cells that will form hair cells to become immunoreactive for TuJ1. A similar timing for TuJ1 expression relative to cell birth was recently demonstrated for regenerating hair cells in the drug-damaged chick basilar papilla in vivo (Stone and Rubel 2000). In streptomycin-damaged utricles in vitro, the peak of supporting cell proliferation occurs by 2 days after the initiation of the drug exposure for the majority of the drug concentrations studied. Assuming that the time it takes postmitotic cells to express TuJ1 is similar in vitro and in vivo, we expected that many of the cells generated at this peak time would be TuJ1-positive by 5 days in vitro.

We have considered a few potential reasons for the apparent delay in hair cell differentiation. First, our culture conditions may slow the rate of hair cell differentiation relative to that seen in vivo, or they may simply slow the rate of TuJ1 expression in committed hair cells. Second, it is possible that most cells that are regenerated during the early phases of recovery from streptomycin in vitro are supporting cells and that hair cells are regenerated at a later times. In the mature undamaged chick utricle in vivo, the majority of ongoing cell divisions result in the formation of a hair cell and a supporting cell (Stone and Rubel 1999, 2000). However, the time-course of hair cell and supporting cell production in the utricle after drug exposure is unknown. Hair cell regeneration may take longer after aminoglycoside exposure. Previous studies have shown that complete morphological recovery of utricular hair cells in vivo requires several weeks or months following exposure to aminoglycosides (Weisleder and Rubel 1993; Dye et al. 1999).

As mentioned above, several laboratories have suggested that new hair cells arise from direct, nonmitotic transdifferentiation of supporting cells (Baird et al. 1993, 1996; Roberson et al. 1996; Adler and Raphael
1996; Adler et al. 1997; Li and Forge 1997; Forge et al., 1998; Zine and Ribeaupierre 1998). One might venture that, in our continuous BrdU exposure experiments, cells with hair cell characteristics that are BrdUnegative represent hair cells that were regenerated as a result of direct transdifferentiation. Unfortunately, this issue cannot be addressed in this study. In order to assure that cells have transdifferentiated in our culture system, we would have to ensure that we could identify BrdU-negative cells that were newly formed in vitro. This would be possible if our lesion paradigm results in complete loss of hair cells in some portion of the utricle. While we detected a lack of stereocilia in the striolar region of some cultured utricles, we cannot be certain that the underlying hair cells are also absent (Sobkowicz et al. 1996; Zheng et al. 1999). The use of the chick utricle as a system with which to study the role of transdifferentiation in hair cell regeneration is further confounded by the fact that a proportion of the resident hair cells in this organ are immature, because of its ongoing hair cell production. Immature regenerated hair cells in the chick basilar papilla exhibit transient resistance to aminoglysocide treatment in vivo (e.g., Hashino and Salvi 1996). Therefore, immature hair cells are likely to persist after our aminoglycoside exposure in vitro. In conclusion, among the population of $\mathrm{TuJ1}$-positive/BrdU-negative cells, we cannot distinguish between cells that survived the aminoglycoside exposure and those that were newly formed in vitro.

\section{ACKNOWLEDGMENTS}

The authors thank Dale Cunningham, Glen MacDonald, David Molea, Valerie Redeker-DeWulf, and Dr. Jialin Shang for their excellent technical support; Janet Clardy and Paul Schwartz for their outstanding photographic assistance; and Drs. Anthony Frankfurter and Guy Richardson for donating their antibodies. This work was supported by National Institutes of Health Grants DC002854, DC002388, DC03696, and DC03944 and by the National Organization for Hearing Research and Oberkotter Foundations.

\section{REFERENCES}

ADLER HJ, RAPHAEL Y. New hair cells arise from supporting cell conversion in the acoustically damaged chick inner ear. Neurosci. Lett. 205:17-20, 1996. DOI:10.1016/0304-3940(96)12367-3.

AdLER HJ, KomedA M, RAPHAEL Y. Further evidence for supporting cell conversion in the damaged avian basilar papilla. Int. J. Dev. Neurosci. 15:375-385, 1997. DOI:10.1016/S0736-5748(96) 00098-6.

Aran JM, Chappert C, Dulon D, Erre JP, Aurousseau C. Uptake of amikacin by hair cellsof the guinea pig cochlea and vestibule and ototoxicity: comparison with gentamicin. Hear. Res. 82:179183, 1995. DOI:10.1016/0378-5955(94)00175-P. 
BAIRD RA, TORRES MA, SCHUFF NR. Hair cell regeneration in the bullfrog vestibular otolith organs following aminoglycoside toxicity. Hear. Res. 65:164-174, 1993.

BAIRD RA, STEYGER PS, SCHUFF NR. Mitotic and nonmitotic hair cell regeneration in the bullfrog vestibular otolith organs. Ann. NY Acad. Sci. 781:59-70, 1996.

BARTOLAMI S, GOODYEAR R, Richardson G. Appearance and distribution of the $275 \mathrm{kD}$ hair-cell antigen during development of the avian inner ear. J. Comp. Neurol. 314:777-788, 1991.

Bhave SA, Stone JS, Rubel EW, Coltrera MD. Cell cycle progression in gentamicin-damaged avian cochleas. J. Neurosci. 15:4618$4628,1995$.

Bhave SA, Oesterle EC, Coltrera MD. Macrophage and microglialike cells in the avian inner ear. J. Comp. Neurol. 398:241-256, 1998. DOI: 10.1002/(SICI) 1096-9861(19980824)398:2 < 241::AID-CNE6 > 3.0.CO;2-0.

CAREYJP, FUCHS AF, RUBEL EW. Hair cell regeneration and recovery of the vestibuloocular reflex in the avian vestibular system. J. Neurophysiol. 76:3301-3312, 1996.

CORWIN JT, COTANCHE DA. Regeneration of sensory hair cells after acoustic trauma. Science. 240:1772-1774, 1988.

COTANCHE DA. Regeneration of hair cell stereociliary bundles in the chick cochlea following severe acoustic trauma. Hear. Res. 30:181-195, 1987.

Cotanche DA, LeE KH, STONE JS, PICARD DA. Hair cell regeneration in the bird cochlea following noise damage or ototoxic drug damage. Anat. Embryol. 189:1-18, 1994.

COTANCHE DA. Structural recovery from sound and aminoglycoside damage in the avian cochlea. Audiol. Neurootol. 4:271-285, 1999.

CRUZ RM, LAMBERT PR, Rubel EW. Light microscopic evidence of hair cell regeneration after gentamicin toxicity in chick cochlea. Arch. Otolaryngol. Head. Neck. Surg. 113:1058-1062, 1987.

Dye BJ, Frank TC, Newlands SD, Dickman JD. Distribution and time course of hair cell regeneration in the pigeon utricle. Hear. Res. 133:17-26, 1999. DOI:10.1016/S0378-5955(99)00046-5.

EASTER Jr SS, Ross LS, Frankfurter A. Initial tract formation in the mouse brain. J. Neurosci. 13:285-299, 1993.

Forge A, Li L, CoRwIN JT, NeVILL G. Ultrastructural evidence for hair cell regeneration in the mammalian inner ear. Science 259:1616-1619, 1993.

Forge A, Li L, NeVILl G. Hair cell recovery in the vestibular sensory epithelia of mature guinea pigs. J. Comp. Neurol. 397:69-88, 1998. DOI:10.1002/(SICI) 1096-9861(19980720)397:1 < 69::AIDCNE6 > 3.0.CO;2-G.

GIROD DA, DuCKerT LG, RubEL EW. Possible precursors of regenerated hair cells in the avian cochlea following acoustic trauma. Hear. Res. 42:175-194, 1989.

GOODYEAR R, RichaRdSON GP. Distribution of the $275 \mathrm{kD}$ hair cell antigen and cell surface specialisations on auditory and vestibular hair bundles in the chicken inner ear. J. Comp. Neurol. 325:243256, 1992.

GOODYEAR R, HOLLEY M, RiCHARDSON GP. Hair and supporting-cell differentiation during the development of the avian inner ear. J. Comp. Neurol. 351:81-93, 1995.

GOODYEAR R, RICHARDSON GP. Pattern formation in the basilar papilla: evidence for cell rearrangement. J. Neurosci. 17:6289_ 6301, 1997.

GRATZNER HG. Monoclonal antibody to 5-bromo- and 5-iododeoxyuridine: A new reagent for detection of DNA replication. Science 218:474-475, 1982

de Groot JC, Meeunsen F, Ruizendaal WE, Veldman JE. Ultrastructural localization of gentamicin in the cochlea. Hear. Res. 50:35-42, 1990.

Hashino E, SAlvi RJ. Changing spatial patterns of DNA replication in the noise-damaged chick cochlea. J. Cell. Sci. 105:23-31, 1993.

HASHINO E, SALVI RJ. Regenerated hair cells exhibit a transient resistance to aminoglycoside toxicity. Brain Res. 720:172-182, 1996. DOI:10.1016/0006-8993(95)01467-5.

Hayashida T, Nomura Y, Iwamori M, Nagai Y, Kurata T. Distribution of gentamicin by immunofluorescence in the guinea pig inner ear. Arch. Oto-Rhino-Laryngol. 242:257-264, 1985.

Hiel H, Err J, Aurousseau C, Bouali R, Dulon D, Aran J. Gentamicin uptake by cochlear hair cells precedes hearing impairment during chronic treatment. Audiol. 32:78-87, 1993.

Hirose K, Hockenbery DM, Rubel EW. Reactive oxygen species in chick hair cells after gentamicin exposure in vitro. Hear. Res. 104:1-14, 1997. DOI:10.1016/S0378-5955(96)00169-4.

JøRGENSEN JM. Regeneration of lateral line and inner ear vestibular cells. In: Regeneration of vertebrate sensory receptor cells. vol 160, Wiley Chichester, 1991, 151-170.

Jørgensen JM, Mathiesen C. The avian inner ear. Continuous production of hair cells in vestibular sensory organs, but not in the auditory papilla. Naturwissenschaften 75:319-320, 1988.

JøRGensen JM, Christensen JT. The inner ear of the common rhea (Rhea americana L.). Brain. Behav. Evol. 34:273-280, 1989.

KATAYAMA A, CORWIN JT. Cochlear cytogenesis visualized through pulse labeling of chick embryos in culture. J. Comp. Neurol. 333:28-40, 1993.

KIL J, WARCHOL ME, CORWIN JT. Cell death, cell proliferation, and estimates of hair cell life spans in the vestibular organs of chicks. Hear. Res. 114:117-126, 1997. DOI:10.1016/S0378-5955(97) 00166-4.

KOMEDA M, RAPHAEL Y. Gentamicin distribution in the basilar papilla: possible association with regenerated hair cell orientation. Hear. Res. 102:81-89, 1996. DOI:10.1016/S0378-5955(96) 00150-5.

KOTECHA B, RICHARDSON GP. Ototoxicity in vitro: effects of neomycin, gentamicin, dihydrostreptomycin, amikacin, spectinomycin, neamine, spermine and poly-L-lysine. Hear. Res. 73:173-184, 1994.

Kuntz AL, Oesterle EC. Transforming growth factor alpha with insulin stimulates cell proliferation in vivo in adult rat vestibular sensory epithelium. J. Comp. Neurol. 399:413-423, 1998. DOI:10.1002/(SICI) 1096-9861(19980928)399:3 < 413::AIDCNE9 > 3.0.CO;2-3.

LAMBERT PR. Inner ear hair cell regeneration in a mammal: identification of a triggering factor. Laryngoscope 104:701-718, 1994.

Lee MK, Tuttle JB, Rebhun LI, Cleveland DW, Frankfurter A. The expression and posttranslational modification of a neuronspecific $\beta$-tubulin isotype during chick embryogenesis. Cell. Motil. Cytoskel. 17:118-132, 1990.

Li L, FORGE A. Morphological evidence for supporting cell to hair cell conversion in the mammalian utricular macula. Int. J. Dev. Neurosci. 15:433-446, 1997. DOI:10.1016/S0736-5748(96) 00102-5.

LINDEMAN HH. Regional differences in sensitivity of the vestibular sensory epithelium to ototoxic antibiotics. Acta Otolaryngol. Stockh. 67:177-189, 1969.

LIPPE WR, WESTBROOK EW, RYALS BM. Hair cell regeneration in the chicken cochlea following aminoglycoside toxicity. Hear. Res. 56:203-210, 1991.

Lopez I, Honrubia V, Lee SC, Schoeman G, BEykirch K. Quantification of the process of hair celll loss and recovery in the chinchilla crista ampullaris after gentamicin treatment. Int. J. Dev. Neurosci. 15:447-461, 1997. DOI:10.1016/S0736-5748(96)00103-7.

Matsui JI, Oesterle EC, Rubel EW. Characterization of damage to the avian vestibular sensory epithelia through an in vitro model using streptomycin. Assoc. Res. Otolaryngol. Abstr. 20:135, 1997a.

Matsui JI, Oesterle EC, Stone JS, Rubel EW. Hair cell differentiation in vitro following aminoglycoside insult. Soc. Neurosci. Abstr. 23:1922, 1997b.

MemberG SP, HaLl AK. Dividing neuron precursors express neuronspecific tubulin. J. Neurobiol. 27:26-43, 1995. 
Molea D, Stone JS, Rubel EW. Class III beta-tubulin expression in sensory and nonsensory regions of the developing avian inner ear. J. Comp. Neurol. 406:183-198, 1999. DOI:10.1002/ (SICI) 1096-9861 (19990405) 406:2 < 183::AID-CNE4 > 3.0.CO; 2-K.

Navaratnam DS, Su HS, Scott SP, Oberholtzer JC. Proliferation in the auditory receptor epithelium mediated by a cyclic AMPdependent signaling pathway. Nat. Med. 2:1136-1139, 1996.

Oesterle EC, Rubel EW. Postnatal production of supporting cells in the chick cochlea. Hear. Res. 66:213-224, 1993.

Oesterle EC, Tsue TT, ReH TA, Rubel EW. Hair-cell regeneration in organ cultures of the postnatal chicken inner ear. Hear. Res. 70:85-108, 1993.

OESTERLE EC, BHAVE SA, COLTRERA MD. bFGF inhibits cell proliferation in cultured inner-ear sensory epithelia. Assoc. Res. Otolaryngol. Abstr. 19:198, 1996.

Oesterle EC, Tsue TT, Rubel EW. Induction of cell proliferation in avian inner ear sensory epithelia by insulin-like growth factorI and insulin. J. Comp. Neurol. 380:262-274, 1997. DOI:10.1002/ (SICI) 1096-9861(19970407) 380:2 < 262::AID-CNE8 > 3.0.CO; 2-1.

Quint E, Furness DN, HaCkney CM. The effect of explantation and neomycin on hair cells and supporting cells in organotypic cultures of the adult guinea-pig utricle. Hear. Res. 118:157-167, 1998. DOI:10.1016/S0378-5955(98)00026-4.

RAPHAEL Y, ALTSCHULER RA. Early microfilament reorganization in injured auditory epithelia. Exp. Neurol. 115:32-36, 1992.

RAPHAEL Y. Evidence for supporting cell mitosis in response to acoustic trauma in the avian inner ear. J. Neurocytol. 21:663671, 1992.

Roberson DF, Weisleder P, Bohrer PS, Rubel EW. Ongoing production of sensory cells in the vestibular epithelium of the chick. Hear. Res. 57:166-174, 1992.

Roberson DW, KreIg CS, Rubel EW. Light microscopic evidence that direct transdifferentiation gives rise to new hair cells in regenerating avian auditory epithelium. Aud. Neurosci. 2:195-205, 1996.

RYALS BM, RUBEL EW. Hair cell regeneration after acoustic trauma in adult Coturnix quail. Science 240:1774-1776, 1988.

SMOLdERS JW. Functional recovery in the avian ear after hair cell regeneration. Audiol. Neurootol. 4:286-302, 1999.

Sobkowicz HM, SLAPNICK SM, August BK. The kinocilium of auditory hair cells and evidence for its morphogenetic role during the regeneration of stereocilia and cuticular plates. J. Neurocytol. 24:633-653, 1995.

Sobkowicz HM, August BK, SlapNick SM. Post-traumatic survival and recovery of the auditory sensory cells in culture. Acta Otolaryngol. (Stockh.) 116:257-262, 1996.

Sobkowicz HM. Development and regeneration of the inner earintroduction. Int. J. Dev. Neurosci. 15:373-374, 1997. DOI: 10.1016/S0736-5748(96)00097-4.

Steyger PS, Burton M, Hawkins JR, SCHuff NR, BAIRd RA. Calbindin and parvalbumin are early markers of non-mitotically regenerating hair cells in the bullfrog vestibular otolith organs. Int. J. Dev. Neurosci. 15:417-432, 1997. DOI:10.1016/S0736-5748 (96)00101-3.

Stone JS, Cotanche DA. Identification of the timing of $\mathrm{S}$ phase and the patterns of cell proliferation during hair cell regeneration in the chick cochlea. J. Comp. Neurol. 341:50-67, 1994.

Stone JS, LeAno SG, Baker LP, Rubel EW. Hair cell differentiation in chick cochlear epithelium after aminoglycoside toxicity: in vivo and in vitro observations. J. Neurosci. 16:6157-6174, 1996.
Stone JS, Oesterle EC, Rubel EW. Recent insights into regeneration of auditory and vestibular hair cells. Curr. Opin. Neurol. 11:17-24, 1998.

StONE JS, RubEL EW. Delta1 expression during avian hair cell regeneration. Development 126:961-973, 1999.

STONE JS, Rubel EW. Temporal, spatial, and morphologic features of hair cell regeneration in the avian basilar papilla. J. Comp. Neurol. 417:1-16, 2000. DOI:10.1002/(SICI) 1096-9861 (20000131) 417:1 < 1::AID-CNE1 > 3.0.CO;2-E.

TANYERI H, LOPEZ I, HonRubia V. Histological evidence for hair cell regeneration after ototoxic cell destruction with local application of gentamicin in the chinchilla crista ampullaris. Hear. Res. 89:194-202, 1995. DOI:10.1016/0378-5955(95)00137-7.

Tsue TT, Watling DL, Weisleder P, Coltrera MD, Rubel EW. Identification of hair cell progenitors and intermitotic migration of their nuclei in the normal and regenerating avian inner ear. J. Neurosci. 14:140-152, 1994.

WARCHOL ME, CORWIN JT. Supporting cells in avian vestibular organs proliferate in serum-free culture. Hear. Res. 71:28-36, 1993.

Warchol ME, Lambert PR, Goldstein BJ, Forge A, Corwin JT. Regenerative proliferation in inner ear sensory epithelia from adult guinea pigs and humans. Science. 259:1619-1622, 1993.

WARCHOL ME, CORWIN JT. Regenerative proliferation in organ cultures of the avian cochlea: identification of the initial progenitors and determination of the latency of the proliferative response. J. Neurosci. 16:5466-5477, 1996.

WARCHOL ME. Macrophage activity in organ cultures of the avian cochlea: demonstration of a resident population and recruitment to sites of hair cell lesions. J. Neurobiol. 33:724-734, 1997. DOI:10.1002/(SICI) 1097-4695(19971120)33:6 < 724::AID-NEU2 $>$ 3.0.CO;2-B.

WeIsLEder P, Rubel EW. Hair cell regeneration in the avian vestibular epithelium. Exp. Neurol. 115:2-6, 1992.

WeISLEDER P, RUbel EW. Hair cell regeneration after streptomycin toxicity in the avian vestibular epithelium. J. Comp. Neurol. 331:97-110, 1993.

Weisleder P, Tsue TT, Rubel EW. Hair cell replacement in avian vestibular epithelium: supporting cell to type I hair cell. Hear. Res. 82:125-133, 1995. DOI:10.1016/0378-5955(94)00169-Q.

WERSÄLL J. Studies on the structure and innervation of the sensory epithelium of the cristae ampullaris in the guinea pig. Acta Otolaryngol. Suppl. (Stockh.) 126:1-85 1956.

WhiteHEAD MC, MOREST DK. The development of innervation patterns in the avian cochlea. Neuroscience. 14:255-276, 1985.

YAMASHITA H, OESTERLE EC. Induction of cell proliferation in mammalian inner-ear sensory epithelia by transforming growth factor alpha and epidermal growth factor. Proc. Natl. Acad. Sci. USA 92:3152-3155, 1995.

Yan HY, Saidel WM, Chang JS, PressonJC, Popper AN. Sensory hair cells of a fish ear: evidence of multiple types based on ototoxicity sensitivity. Proc. R. Soc. Lond. B Biol. Sci. 245:133-138, 1991.

YAN HY, POPPER AN. Auditory sensitivity of the cichlid fish Astronotus ocellatus (Cuvier). J. Comp. Physiol. 171:105-109, 1992.

Zheng JL, Helbig C, GaO WQ. Induction of cell proliferation by fibroblast and insulin-like growth factors in pure rat inner ear epithelial cell cultures. J. Neurosci. 17:216-226, 1997.

ZHENG JL, GAO WQ. Analysis of rat vestibular hair cell development and regeneration using calretinin as an early marker. J. Neurosci. 17:8270-8282, 1997.

Zheng JL, KeLLer K, GAO WQ. Immunocytochemical and morphological evidence for intracellular self-repair as an important contributor to mammalian hair cell recovery. J. Neurosci. 19:2161-2170, 1999.

ZINE A, RIBEAUPIERRE FD. Replacement of mammalian auditory hair cells. Neuroreport. 9:263-268, 1998. 